\title{
Living With the IMF: A New Approach to Corporate Governance and Regulation of Financial Institutions in Korea
}

\author{
By \\ Hwa-Jin Kim*
}

\section{INTRODUCTION}

Improving corporate governance is not easy, particularly for newly industrialized economies. Policymakers in such economies have little experience in controlling such problems as shirking and greed when they appear in the sophisticated organizational form of the modern corporation. As a result, they must turn to the more advanced economies to find a role model for institutional reforms and improvements. Comparative corporate governance is an important area of study in this regard.

A recent study on comparative corporate governance noted that "[n]ational governance systems turned out to be more adaptable in function, and therefore more persistent in form, than the prophets of convergence expected." ${ }^{1}$ This study also suggested that formal convergence should come as a last resort due to the substantial political and social costs involved. ${ }^{2}$ This view delivers important messages to scholars and policy-makers of some newly industrialized countries who are struggling with corporate governance issues in order to improve the

* Senior Consultant, Woo, Yun, Kang, Jeong \& Han, Seoul, Korea; Lecturer, Research and Training Institute of the Korean Supreme Court. Member of the New York Bar. LL.M., Harvard Law School, 1994; LL.M., Northwestern University, 1993 (Raymond Fellow); Dr. Jur., LudwigMaximilians-University of Munich, Germany, 1988 (Adenauer Scholar); B.S., Seoul National University, Korea, 1983. The author gratefully acknowledges the invaluable comments of Professors Kon Sik Kim and Chang Hee Lee, Seoul National University. The author also gratefully acknowledges insightful comments of Professor Ronald J. Gilson, Stanford Law School, at the Symposium on Globalization and Law for the Twentieth Century, sponsored by Seoul National University College of Law. The author wishes to thank Professors Lucian A. Bebchuk, Reinier Kraakman, Howell Jackson, and William P. Alford, Harvard Law School; Bruno Simma, Ludwig-Maximilians-University of Munich; Sang-Hyun Song, Seoul National University/Harvard Law School; Chul Song Lee, Hanyang University; and Judge Young-Joon Mok, Research and Training Institute of the Korean Supreme Court, for academic inspiration and support for his studies.

1. Gilson, Globalizing Corporate Governance: Convergence of Form or Function 3-4 (discussion paper for the Symposium on Globalization and Law for the Twentieth Century, sponsored by Seoul National University College of Law, October 10-1 1th, 1997) [hereinafter Gilson, Globalizing Corporate Governance].

2. Id. at 7 . 
competitiveness of their countries' enterprises in global markets. ${ }^{3}$ In their efforts to find an optimal structural relationship between capital markets, financial institutions, and corporate governance, they must be aware of the political and social costs involved in radical institutional reforms that go beyond the pathdependent limit of their institutions. The functional approach to corporate governance issues should come first in those economies as elsewhere.

Korea, one of the most dynamic economies of the global market, should benefit from this reasoning. Korea has recently recognized the importance of the systematic improvement of its industrial organization and corporate governance practices. The globalization of Korean firms' operational and financing activities and the internationalization of its capital markets have initiated, and even greatly contributed to, recent efforts toward various reforms and reform proposals. The process of reform was hastened by the foreign exchange crisis of 1997 and the consequential involvement of the international lending agencies such as the International Monetary Fund (IMF) and the World Bank in the restructuring of Korean industries.

In this article, I will discuss the current system and developments in corporate governance in Korea and address important lessons Korea has derived from recent studies on comparative corporate governance. The issue of corporate governance of banks is given particular attention in view of the recent failures of some large Korean conglomerates and the consequential negative impact on major Korean banks.

Part I describes the traditional "Korean institution" and its problems, singling out the so-called Chaebol-question and representative issues of corporate governance in Korea. Recent developments in Korean markets in terms of industrial restructuring under the IMF-mandated plan are also described. Part II explains and analyzes various corporate governance mechanisms newly introduced in Korea, focusing in particular on the Korean efforts to cultivate markets for corporate control. Part III tackles the important issue of corporate governance of banks and banks' participatory investments in Korea. Part IV explores the relationship between market internationalization and globalization of financing and corporate governance with reference to the case of Korean firms. This section also describes and analyzes the influence of international regulation of financial institutions on the governance of local banks and the new role of institutional investors in the Korean market.

This article is intended to be something more than a case study. One point made throughout this article is that the internationalization of capital markets, both inbound and outbound, will greatly improve corporate governance in Korea and elsewhere. Prudential regulations, as well as active transactions in interna-

3. For efforts in emerging market economies, see Bernard Black \& Reinier Kraakman, $A$ SelfEnforcing Model of Corporate Law, 109 HaRv. L. REv. 1911 (1996) (developing a "self-enforcing" model of corporate law for emerging markets based on a case study of the Russian Federation). But cf. Roberta Romano, A Cautionary Note on Drawing Lessons from Comparative Corporate Law, 102 YALE L. J. 2021, 2036 (1993) (noting that "no tight connection [can] be demonstrated between corporate governance institutions and international competitiveness"). 
tional financial markets, have strongly promoted the functional convergence of corporate governance institutions. ${ }^{4}$ The involvement of international lending agencies in the industrial restructuring process of the Korean economy has subjected Korean firms and banks to the harsh, but fair, discipline of international financial markets. The converging process of Korean corporate governance institutions into international standards is mandated by the discipline of international financial markets. By identifying the main trends and perspectives of this convergence, Korean policy-makers may have a better idea of the way they want to lead the Korean economy in the future.

I.

\section{Problems With the "Traditional" Institution}

\section{A. The Korean Institution}

The traditional corporate governance institution in Korea is characterized by large groupings of related corporations under highly concentrated family or individual control and a unique pattern of unrelated diversification. ${ }^{5}$ In terms of finance, Korean firms are highly leveraged but do not have the harsh discipline normally associated with debt. ${ }^{6}$ Authoritarian military governments began building Korea's economic system since the 1960s and have traditionally favored big businesses through the provision of immense bank loans ("directed lending"). The Korean populace tolerated the Chaebol's rise in the belief that they greatly contributed to the competitiveness of the Korean economy in global markets. ${ }^{7}$

The Chaebol, however, cannot necessarily be understood as a pattern of corporate governance. Rather, the term Chaebol describes a concentration of economic power and a pattern of doing business through unrelated diversifica-

4. Similarly, in one of my previous studies, I suggested that market internationalization and new financial institutions' regulations of the European Union may change the traditional governance pattern and ownership structure of German corporations, roughly towards the one prevailing in the United States. See Hwa-Jin Kim, Markets, Financial Institutions, and Corporate Governance: Perspectives from Germany, 26 LAw \& PoL'y INT'L Bus. 371, 394-99 (1995). Cf. Curtis J. Milhaupt, Property Rights in Firms, 84 VA. L. Rev. 1145, $1185-89$ (1998) (suggesting that the recent developments in Korea in terms of the currency and debt crisis support the convergence-from-competition hypothesis).

5. The Korean economy and corporate governance institutions are path dependent and are extremely sensitive to initial conditions set in the 1960s. For the concept of path dependency, see Mark J. Roe, Chaos and Evolution in Law and Economics, 109 HARv. L. Rev. 641 (1996). The path dependency of the Korean system takes the common semi-strong form. $C f$. id. at 648-50. Recent scholarship emphasizes the importance of path dependence in determining the ownership structure of large public companies and corporate law in general. See id. at 643-58; Black and Kraakman, supra note 3, at 1974-77; Mark J. Roe, Strong Managers, Weak Owners: The Polttical Roots of American Corporate Finance passim (1994).

6. For an excellent account of the disciplinary effects of high leverage on corporate management, see generally George ANDERs, Merchants of DebT, chs. 8-9 (1992).

7. See generally Kon Sik Kim, Chaebol and Corporate Governance in Korea, ch.1 (University of Washington Dissertation 1995) [hereinafter KS Kim, Chaebol and Corporate Governance]; Myung Hun Kang, The Korean Business Conglomerate: Chaebol Then and Now (1996). See also Meredith Woo-Cumings, How Industrial Policy Caused South Korea's Collapse, WALL St. J. Europe, Dec. 9, 1997, at 8. 
tion. The traditional Korean system can be classified as a bank-centered capital market system in which the banks lack ownership of the commercial enterprises. Most of these enterprises, even those ranked in the Fortune International 500, such as Samsung or Hyundai, are family-controlled. According to the then Korean Securities Supervisory Board, the listed Korean firms' major shareholders had an average shareholding of 33.31 percent as of the end of October $1997 .{ }^{8}$ It has recently been reported that out of 769 listed Korean corporations, some 380 are directly controlled by their major shareholders as full-time directors. ${ }^{9}$ These enterprises are also highly leveraged. Banks and other financial institutions have tremendous amounts of credit outstanding with these large enterprises with significant security interest in these firms' assets. Neverthless, banks have been rather indifferent to corporate governance issues, partly because they have been under the government's influence, and partly because they have lacked motives and skills to effectively monitor these enterprises. ${ }^{10}$

As a result, the debt-to-equity ratios of some large Korean firms has become extremely high. The average debt to equity ratio of the 30 largest Korean conglomerates accounted for 519 percent of their shareholders' equity by the end of 1997. ${ }^{11}$ Hanbo Steel's peak of 1,893 percent in June 1996, Sammi Steel's peak of 1,762 percent in December 1996, and Woosung Construction's peak of 3,323 percent in June 1997 are the most conspicuous examples. Such unusually high debt-to-equity ratios have been made possible through the widespread practice of "cross guarantees" between member firms within corporate groups. ${ }^{12}$ The volume of cross guarantees within the 30 largest Korean conglomerates reached 469 percent of their shareholders' equity by April 1, 1993. The ratio decreased to 91.34 percent by April $1,1997,{ }^{13}$ but this decrease was due largely to the bankruptcy of two large Korean conglomerates, Halla and Jinro, in 1997.

8. See Korea Herald, Nov. 13, 1997, at 11.

9. See Joong-Ang ILbo, Sept. 23, 1997, at 35.

10. Although Japanese firms have long been role models for Korean Chaebols, the Korean system differs significantly from the Japanese in terms of commercial banks' ownership interest in and effective monitoring of borrower companies. Some view the Korean system as similar to that of the Japanese. See, e.g., Alan Murray, Asia's Financial Pain Makes U.S. System Look Like a Winner, W ALL St. J. Europe, Dec. 9, 1997, at 1, 7 (arguing that the American system, with its emphasis on the short-term and shareholder activism, is doing far better than the Japanese one with long-term relationships of cross-shareholdings and preferential bank financing). But see Milhaupt, supra note 4, at 1158-84 (showing non-convergence of corporate governance systems in the United States, Japan and Korea). For the Japanese institution, see Curtis J. Milhaupt, A Relational Theory of Japanese Corporate Governance: Contract, Culture, and the Rule of Law, 37 HARV. INT'L L. J. 3 (1996); Ronald J. Gilson and Mark J. Roe, Understanding the Japanese Keiretsu: Overlaps Between Corporate Governance and Industrial Organization, 102 YALE L. J. 871 (1993); Kang, supra note 7, at 63-91; Masahiko Aoki, Toward an Economic Model of the Japanese Firm, 28 J. Econ. LrT. 1 (1990); J. Mark Ramseyer, Takeovers in Japan: Opportunism, Ideology and Corporate Control, 35 UCLA L. Rev. 1 (1987). See also Mark G. Robilotti, Codetermination, Stakeholder Rights, and Hostile Takeovers: A Reevaluation of the Evidence from Abroad, 38 HARv. INT'L L. J. 536 (1997) (critically analyzing the stakeholder corporate governance debate in comparative perspectives).

11. See Chosun Ilbo, April 16, 1998, at 3.

12. See Steve Glain and Namju Cho, Chaebols Gasp Under Suffocating Debt, AsIan WaLL ST. J., Dec. 23, 1997, at 1, 7 (reporting severe credit crunch of large Korean firms).

13. See infra p. 93 (Table 1). 
These two conglomerates went into bankruptcy with cross guarantees of 891 percent and 473 percent of shareholders' equity, respectively.

As some large Chaebols (Hanbo, Sammi, Jinro, Dainong, Kia, New Core, Haitai, and Halla) went into bankruptcy in 1997, Korean banks lost credit in the market due to their bad loans to the failed firms. Korean commercial banks and merchant banks were saddled with 28.52 trillion won and 3.89 trillion won, respectively, in non-performing loans by October $1997 .{ }^{14}$ The result was general skepticism about the soundness of the Korean market and system. The international financial community soon realized that the Korean economy had serious structural problems and that the government had not taken leadership in regulatory reforms. ${ }^{15}$ As a result, foreign investors quickly withdrew from the Korean market and the Korean currency fell in international financial markets. ${ }^{16}$ The stock market index also declined to a ten-year low. During the turmoil of 1997, the number of insolvent firms placed under the supervision of the Korea Stock Exchange reached seventy-two, representing ten percent of all listed firms. As the Korean government's emergency package for market-boosting financial stabilization measures, including the kick-off plan of Big Bang failed to satisfy markets, Korea ultimately applied for the bailout funds with the IMF on November 21,1997 , one year after joining the OECD. Korea was then forced to restructure its financial industry and industrial organization under the guidance of the IMF. ${ }^{17}$

14. See Gov't to Allow Wider Won Price Swing, Korea Herald, Nov. 20, 1997, at 1. As of the end of December 1998, total non-performing loans (loans classified as either substandard, doubtful or estimated loss), of 22 Korean commercial banks stood at 22.22 trillion won. See Korea Financial Supervisory Commission, Bank Nonperforming Loans at End-December, 1998 (visited March 5, 1999) <http://www.fsc.go.kr/kfsc/board/1 1/pr_0303.html>.

15. See Korean Leadership, WAll St. J. Europe, Nov. 25, 1997, at 10 (noting that the Chaebols are "a drag on the economy" and the Korean developmental model is "hopelessly outdated and outclassed by market forces").

16. See Hal S. Scott \& Philip A. Wellons, International Finance: Transactions, PolICY, AND Regulation 32-36 (5th ed. 1998).

17. See Mark L. Clifford, Korea's Crisis, Bus. WK. (Asian Edition), Nov. 24, 1997, at 18-21; Michael Hirsh, Jeffrey Bartholet and Lee Pyongchong, Seoul Calls for Help, Newsweek, Dec. 1, 1997, at 34-37; Seoul, IMF Agree on \$55-bil. Bailout Deal, Korea Herald, Dec. 4, 1997, at 1; Bob Davis, Bitter Medicine: Korea Plays Adverse Patient to IMF's Rescue Team, AsIan WaLl ST. J., March 3, 1998, at 1, 9. Even after the IMF bailout, Korea careened toward the catastrophe of a default. The near-bankrupt Korean economy was finally rescued by G-7 countries' decision of December 24, 1997, for advancement of the bailout package. See Paul Blustein \& Clay Chandler, Behind Korean Bailout, Korea Herald [Washington Post Service], Dec. 30, 1997, at 6 (reporting that there had been talk [in Washington] of letting Korea fail and "pay the price for years of economic mismanagement"); David Wessel, South Korean Bailout Evokes Some Tough Questions, AsLaN WALl St. J., Dec. 29, 1997, at 6 (citing some hard-liners who say world governments and the IMF are making a big mistake by insulating private investors and lenders from the discipline of the market); Michael Duffy, The Rubin Rescue, TIME, Jan. 12, 1998, at 12-15. Korea's total foreign debts were tallied at $\$ 156.9$ billion at the end of November 1997. See Korea's Foreign Debts Total $\$ 156.9$ Bil. by IMF Standards, Korea HeRALD, Dec. 31, 1997, at 1. Most of the country's shortterm corporate foreign debts were restructured in January 1998. See Stephen E. Frank \& Namju Cho, Korea, Creditors Finalize Debt-Restructuring Deal, Asian Wall St. J., January 30-31, 1998, at 3 . 


\section{B. Inordinate Efforts to Change Complimentary Institutions?}

Even before the advent of this recent turmoil, Korean policy-makers and scholars believed that their system was relatively inefficient in comparison to those of the United States, Germany, or Japan. Korean scholars, particularly, increasingly believed that the existing Korean model could no longer effectively compete in the global market. Consequently, the Korean government's initiative towards dilution of the ownership concentration, ${ }^{18}$ particularly in large firms, has been strongly supported by public opinion. The Berle-Means corporation, with separated ownership and control, has long been a superior ideal in the minds of the Korean public. It is widely believed that professional managers, not being the "owners," 19 would be able to rationalize outbound corporate relationships with the government, financial institutions, securities markets and internal reform operations without a heavy conflict of interest. Furthermore, Korean law does not allow dual class voting. ${ }^{20}$ By now, it appears that there is a consensus that the U.S. system, with its dispersed ownership structure and efficient securities market, should be imported to rationalize the Korean system. The IMF-mandated reforms will support such developments.

However, it is questionable if this is the most efficient way to achieve rationalization, especially in view of recent trends in the United States to bridge ownership and control of public companies in order to diminish agency costs. This course of action could also be tainted by the common emotional drive for "Chaebol-bashing." 11 Perhaps too much emphasis has been placed on institutional changes regarding ownership structure and structural relationships between capital markets and business corporations. The basic Korean approach has been to adapt the institution to fit a fixed political or social goal, no matter what the political or social costs. In such an environment, there is not much

18. In order to reduce the burden of servicing high-interest bearing debts, Korean firms will continuously have to increase capital. This will lead to dilution of ownership concentration and ultimately promote the separation of ownership and control. Since the cost of capital of Korean shareholders will continue to be very high because of high interest rates, new capital injections are likely to come from foreign investors.

19. This widely used term is a misnomer. No one can claim to be the owner of a public corporation unless he or she holds a 100 percent sharehold of the firm, which is not possible. Otherwise, he or she can just control the firm, identifying personal interest with that of the company in most cases. However, the agency problem still exists in view of the non-controlling shareholders' interest especially when the controlling shareholder holds less than 50 percent. In Korea, substantial agency costs already exist in such cases where the controlling shareholder-manager mismanages the firm and/or causes wealth transfer from non-controlling shareholders to himself/herself. In the latter case, the cost will be borne by non-controlling shareholders only, the controlling shareholder excluded. The term "owner" is not only a misnomer, but also contributes to distortion of reality.

20. The Korean Commercial Code accepts the one share, one vote principle. See Art. $369(1)$.

21. It should be noted that there is a widespread confusion in Korea of general corporate governance issues with the so-called "Chaebol-question." To be sure, the latter should be understood in terms of the unique path dependency of the Korean institution. However, the issue is better approached through the sound reasoning against concentration of economic power. It would be unfair to declare that the Chaebols are the source of all failures in the Korean model. Transparency and accountability of corporate management are standards applicable to any corporation in Korea. On the other hand, it would be also unfair to apply the fundamentals of the "Chaebol-policy" to medium or small firms. Some of the newly introduced rules in the Korean Securities and Exchange Act exemplify the confusion of the above two conceptually distinct issues. 
room left for reform through functional improvements of the existing regime, whether it be political or industrial.

\section{Who Replaces Poorly Performing Managers?}

Will Korea be able to find a functional solution to this central question of corporate governance ${ }^{22}$ within its path dependent limits? Although it has tried to change the ownership structure of firms through a rather formal approach, it also has tried to respond to managerial accountability problems through a functional approach. The recent general revision of the Commercial Code and Securities and Exchange Act described below evidences this. However, the point of these revisions was the protection of minority investors, not a systematic remaking of the corporate governance institution. The latter was only recently identified as an important goal since the latest involvement of the international lending agencies in reforms of the Korean economy.

Indeed, there has been no entity which has been able to replace the poorly performing managers in Korea. The managers themselves are major controlling shareholders. In most cases, Korean corporate boards are nominal organizations under direct control of these controlling shareholders. The troubling question here is: who controls the controlling shareholder-managers of Korean firms? ${ }^{23}$ Although Korean law recognizes the concept of managers' fiduciary duty of loyalty, it falls short of the standards set in American corporate law. Derivative litigation has existed only in statute ${ }^{24}$ until recently, ${ }^{25}$ and its deterrence and disciplining influence will probably be nonexistent because of the absence of class action and contingency fee devices. ${ }^{26}$ Recent developments indicate that it

22. For a good overview of mechanisms to replace inefficient management, see Park McGinty, Replacing Hostile Takeovers, 144 U. PA L. REv. 983, 990-99 (1996).

23. Here we come back to the question raised by Alchian and Demsetz: "[W]ho will monitor the monitor?" Armen Alchian and Harold Demsetz, Production, Information Costs, and Economic Organization, 62 Am. Econ. Rev. 777, 782 (1972). See also Ronald J. Gilson, A Structural Approach to Corporations: The Case Against Defensive Tactics in Tender Offers, 33 STAN. L. REv. 819,835 n. 61 (1981).

24. See Arts. 403-406 of the Korean Commerclal Code. Under Art. 403(1) of the CommerCIAL CoDE, shareholders holding 1 percent (previously 5 percent under the pre-1998 version law) of the company's issued and outstanding shares may file a derivative suit. The amount of reimbursed attorneys fees for a successful shareholder is subject to certain limits ruled by the Supreme Court. See Art. 99-2 of the Korean Code of Civil Procedure.

25. The recent turmoil in the financial market has resulted in few derivative lawsuits in Korea. Further, the new practice in Japan is expected to influence the recent insurgence of derivative litigation in Korea. In Japan, shareholders derivative litigation is gaining importance in corporate governance of Japanese firms. See Shiro Kawashima \& Susumu Sakurai, Shareholder Derivative Litigation in Japan: Law, Practice, and Suggested Reforms, 33 STAN. J. INT'L L. 9 (1997); Milhaupt, supra note 4 , at 55-57.

26. For skeptical views on the benefits of derivative litigation, see Roberta Romano, The Shareholder Suit: Litigation without Foundation?, 7 J. L. ECON. \& ORG. 55, 84 (1991) (finding little empirical evidence of specific deterrence and concluding that "shareholder litigation is a weak, if not ineffective, instrument of corporate governance"); Daniel R. Fischel \& Michael Bradley, The Role of Liability Rules and the Derivative Suit in Corporate Law: A Theoretical and Empirical Analysis, 71 Cornell L. REv. 261 (1986) (casting doubt on the assumption that liability rules enforced by derivative suits play a fundamental role in aligning the interests of managers and investors). For the mixed data on the effect of changes in laws concerning derivative suits, see Michael Bradley \& Cindy A. Schipani, The Relevance of the Duty of Care Standard in Corporate Governance, 75 IowA 
may be the banks' role to demand accountability from management. However, Korean banks, deep in trouble themselves, have a strong voice only in those cases where their debtor firms face fatal financial failure. Would they also be active in "peace time"?

It is widely believed in Korea that the solution should be found in an active market for corporate control and with institutional investors' enhanced activism. The internationalization of the Korean capital markets, either by voluntary efforts or by the IMF-mandated plans, ${ }^{27}$ will contribute to the shaping of the new regime. For now, Korea has decided to model its capital markets after the American system. As far as the capital market is concerned in the Korean economy, adapting to the U.S. system would not require radical institutional changes. For example, Korean efforts to seek strong venture capital markets with the opening of the Korea Securities Dealers Automated Quotation System (KOSDAQ) may be a good test for a successful adaptation.

\section{Remaking of the Korean Institution Under the IMF-Mandated Plan}

Immediately after its decision to seek a bailout fund from the IMF, the Korean government started to accelerate the corporate and financial restructuring process. As the IMF was expected to ask for such a restructuring anyway, and the Korean government had long been realizing its inevitability, it came as no great surprise. The Chaebols also started paring down businesses. ${ }^{28}$ Throughout 1998, many Korean firms and financial institutions went through restructuring, private workouts, strategic alliance talks with foreign firms, and domestic and international mergers and acquisitions transactions. ${ }^{29}$ In particu-

L. Rev. 1 (1989); Elliott J. Weiss \& Lawrence J. White, Of Econometrics and Indeterminacy: A Study of Investors' Reactions to "Changes" in Corporate Law, 75 CAL. L. Rev. 551 (1987).

27. For the full text of the Korean government's Letter of Intent with the Memorandum on the Economic Program (hereinafter Korea-IMF Memorandum) submitted to the IMF, see Chosun LLBo, Dec. 6, 1997, at 12. For the full text of the second and third packages submitted to the IMF by the Korean government, see Joong-ANg lLbo, Dec. 26, 1997, at 5 and MAEIL KyongJe, Feb. 18, 1998, at 3 , respectively. The implementation of the restructuring plans are coordinated by the Structural Reform Planning Unit created by the Korea Financial Supervisory Commission. For various discussions and opinions on the Korea-IMF deal, see Korea's IMF Negotiations, Wall St. J. Europe, Dec. 3, 1997, at 8; Seong C. Gweon, Why is IMF Bad for the Market?, Korea Herald, Dec. 10, 1997, at 8; Michael Schuman and Namju Cho, Is Korean Bailout the Right Medicine?, Wall St. J. EUROPE, Dec. 8, 1997, at 5; Robert J. Fouser, Antiforeignism, Korea Herald, Dec. 17, 1997, at 6; Editorial, Hurdles Ahead for South Korea, N.Y. Times, Jan. 2, 1998, at 16; Ajay Kapur, Bad Medicine from the IMF, Asian WALL ST. J., Jan. 15, 1998, at 6. See also George P. Shultz, William E. Simon and Walter B. Wriston, Who Needs the IMF?, Asian Wall St. J., Feb. 4, 1998, at 8; David Sacks and Peter Thiel, The IMF's Big Wealth Transfer, Asian Wall St. J., March 12, 1998, at 6; Lawrence Summers, The IMF: Good for Donors Too, Asian WaLl St. J., March 30, 1998, at 10; What's an IMF For?, Asian W All St. J., April 7, 1998, at 10; The IMF Crisis, Asian Wall St. J., April 16, 1998, at 8; David Rockefeller, Why We Need the IMF, Wall St. J. Europe, May 11,1998 , at 10.

28. See Michael Schuman, Ssangyong's Restructuring Gives It a Fighting Chance, Astan Wall St. J., Dec. 29, 1997, at 1, 5.

29. Ninety-three merger cases among listed Korean firms have been reported in 1998. See MaEI KyONGJE, Dec. 30, 1998, at 19. The following web sites provide useful data and information on recent developments in Korea in terms of industrial and corporate restructuring: The Korea Financial Supervisory Commission <http://www.fsc.go.kr>; The Korea Fair Trade Commission $<\mathrm{http}: / / \mathrm{www} . \mathrm{ftc} . \mathrm{go} . \mathrm{kr}>$; The Korean Ministry of Finance and Economy <http://www.mofe.go.kr>; 
lar, Korea's five largest Chaebols have tried to agree on so-called "Big Deals," the exchange or consolidation of big businesses under the government's guidance. $^{30}$

Because it was believed that the Korean financial crisis was started in part by the loss of foreign investors' confidence in the governance of large Korean corporations and banks, ${ }^{31}$ the Korean government has started to focus on this aspect and review the regulatory infrastructure again for possible reform as agreed with the IMF. As it is also widely believed that the inefficient governance of large companies and banks are one of the sources of the troubles Korea now faces, ${ }^{32}$ various reforms in terms of industrial policy and corporate governance have been planned and are expected to be implemented.

The package developed by the IMF in consultation with the Korean government includes several measures for improving of governance institutions of Korean firms. ${ }^{33}$ According to the Korea-IMF Memorandum ("the Memorandum"), the Korean government recognized "the need to improve corporate governance and the corporate structure." 34 Toward that end, the Korean government and the IMF agreed that: "transparency of corporate balance sheets (including profit and loss accounts) will be improved by enforcing accounting standards in line with generally accepted accounting practices, including independent external audits, full disclosure, and provision of consolidated statements for business conglomerates." ${ }^{35}$ The Memorandum also provides that

and the Korean Ministry of Commerce, Industry and Energy <http://www.mocie.go.kr>. Cf. The Korea Stock Exchange <http://www.kse.or.kr>; Korea Asset Management Corporation <http:// www.kamco.or.kr>; Korea Federation of Banks <http://www.kfb.or.kr>; The Korea Securities Dealers Association <http://www.ksda.or.kr>; Korea Investment Trust Companies Association <http://www.kitca.or.kr>; The Federation of Korean Industries <http://www.fki.or.kr>.

30. See Korea Financial Supervisory Commission, Agreement for the Restructuring of the Top 5 Chaebol, December 7, 1998 (visited March 5, 1999) <http://www.fsc.go.kr/kfsc/board/11/ 981208-1.html>.

31. See Han-Guk Kyongse Shinmun, Nov. 24, 1997, at 3 (analysing possible impacts of IMF bailout); id., Nov. 6, 1997, at 20 (reporting foreign investors' frustration in Korean firms' ignorance of minority shareholder interest and non-transparent management and accounting practices).

32. See, e.g., Tony Emerson \& B. J. Lee, Foreign Medicine, NewsweEk, Dec. 15, 1997, at 41 ("To be fair, Chaebol owners were simply taking advantage of the system .... And to raise money by selling stock would have diluted the owners' control over family enterprises. So they borrowed and borrowed, knowing that the larger they got, the less likely the government would ever allow them to fail .... By forcing Chaebol to sell majority stockholdings, the IMF deal could not only topple this pyramid [of debt], but eventually the Chaebol owners themselves."); Fred Hu, Should China Grow Chaebol?, Astan Wall St. J., Dec. 18, 1997 (Korean lessons to China).

33. The international lending agencies like the IMF and World Bank regularly extend loans with "conditionality". The concept of "conditionality" does not exist in private lending. But it is not very different from security arrangements on loans of the private sector. To be sure, it is understood that the breach of the agreement with an international lending institution does not constitute the violation of international law per se. However, any default in implementation of such an agreement will limit further borrowing and lower the country's credit rating, which shall exert far greater detrimental impacts on the economy than any cause of legal action might do. See generally Harold James, International Monetary Cooperation Since Bretton WoOds 322-35 (1996); William A. McCleary, The Design and Implementation of CondtTionality, in Restructuring Economies in Distress: Policy Reform and the World Bank 197-215 (Vinod Thomas et al. eds. 1995).

34. See Korea-IMF Memorandum, supra note 27 , at No. 34 .

35. Id. 
" $[t]$ he commercial orientation of bank lending will be fully respected and the government will not intervene in bank management and lending decisions (except for prudential regulations)." 36 Directed lending shall immediately be eliminated. ${ }^{37}$ Further, the Korean government shall formulate, with the assistance of international lending agencies, a plan "to encourage the restructuring of corporate finances, including measures to reduce the high debt-to-equity ratio of corporations, develop capital markets to reduce the share of bank financing by corporations, and change the system of cross guarantees within conglomerates." 38 The implementation of this program began in early 1998 and has resulted in substantial regulatory changes.

II.

\section{Functional Approaches to Corporate Governance Issues}

\section{A. Recent Statutory Changes}

The Korean government's recent efforts towards implementing a new regulatory environment to promote an efficient function of corporate governance mechanisms and an active market for corporate control shows that the functional approach to corporate governance issues is slowly being put into place in Korea. In particular, the Korean Securities and Exchange Act (KSEA) and the Commercial Code have been amended to reflect the changed circumstances in the capital markets and to reflect Korean firms' new pattern of doing business and methods of financing. The government has also introduced numerous provisions that promote corporate restructuring and mergers and acquisition in Korea. At the same time, the new provisions are designed to protect unsophisticated investors under the changed regulatory environment. Interestingly, the new Securities and Exchange Act addresses many of the corporate governance issues that have traditionally been regarded as within the domain of the Commercial Code.

\section{The New Securities and Exchange Act ${ }^{39}$}

The KSEA, effective from April 1, 1997, has substantially improved the status of minority shareholders in listed Korean companies. To promote transparency and managerial accountability, it provides minority shareholders with the right to check and/or challenge management by less restrictive procedural requirements than those provided for in the Commercial Code. The requirements have been lessened further through the partial amendments to the KSEA in February and May 1998, as an implementation of the Korean government's

36. Id.

37. Id.

38. See id. at No. 37. To strengthen market discipline, the Korean bankruptcy laws shall be reformed so that their orderly function without government interference will be made possible. $I d$. at No. 35 prohibits "government subsidized support or tax privileges" to bail out individual corporations. The Korean bankruptcy laws have been amended in February 1998 to introduce more strict substantial requirements and facilitate the court proceedings.

39. For an excellent description of the Korean securities market and the (old) SECURITIES AND Exchange Act, see Joon Park, Internationalization of the Korean Securities Market, 7 INT'L TAX \& Bus. LAW 1 (1989). 
agreement with the IMF. Now, shareholders holding less than one percent of a listed company's issued and outstanding shares may exercise certain shareholder's rights, including the filing of a derivative suit, provided that they satisfy some technical requirements. ${ }^{40}$ Shareholders holding $0.01 \%$ of a listed company's issued and outstanding shares may file a derivative suit, provided that they acquired their shares at least six months prior and maintained the holding continuously until the filing date. ${ }^{41}$

The new system has been widely welcomed by the Korean legal and academic communities. It is regarded as an advanced mechanism for a more balanced relationship between controlling and minority shareholders. Indeed, the institutional reform hastened by the recent economic crisis has initiated new shareholder activism in Korea that is led by a group of highly motivated scholars and lawyers. The advocates of minority shareholders' rights have been successful so far in raising corporate governance issues at some large Korean companies such as Samsung Electronics and SK Telecom. ${ }^{42}$ These highly publicized victories for shareholder democracy, combined with foreign investors' active involvement, ${ }^{43}$ is expected to greatly contribute to the improvement of corporate governance in Korea. However, it remains to be seen whether the new system can function effectively without being abused by bad-faith shareholders who want to utilize it in a control contest situation. The new provisions regarding mergers and acquisitions will be discussed separately below.

\section{The New Commercial Code}

A generally revised new Korean Commercial Code (KCC), went into effect on October 1, 1996. The new amendments to the KCC deal mainly with the section governing stock corporations and have a substantial impact on corporate governance. The official comments to the amendments declare that they reflect changed social and economic circumstances in Korea and are intended to promote competitiveness of Korean enterprises in an era of internationalization of business in Korea.

First of all, a quorum requirement for general shareholders' meetings is abolished. Now, no direct quorum requirement exists unless a company's Articles of Incorporation otherwise provide. ${ }^{44}$ To be sure, new voting require-

40. See Art. 191-13 of the KSEA.

41. See Art. 191-13 (1) of the KSEA. Minority shareholders of the Securities Investment Companies can exercise their shareholders' rights under the rules provided by the KSEA without any regard to the listing of the stocks at the Korea Stock Exchange or KOSDAQ. Further, the $0.01 \%$ requirement is waived for the shareholders of the Securities Investment Companies, i.e., any shareholder holding at least one share can bring the derivative suit. See Art. 84 (3) of the Securrries InVESTMENT COMPANY ACT.

42. See, e.g., Chosun ILbo, March 28, 1998, at 8 (reporting that the annual shareholders meeting of Samsung Electronics took more than 13 hours due to active discussion on corporate governance issues); ChOSUN ILBO, March 27, 1998, at 9 (reporting that SK Telecom accepted minority shareholders' request for managerial transparency).

43. See Part IV, B below.

44. See Art. 368 of the KCC. 
ments ${ }^{45}$ have the effect of imposing a de facto quorum requirement. ${ }^{46}$ However, they are substantially more liberal than those imposed under the pre-1996 law. This new rule is regarded as pro-management due to the newly created flexibility for holding general shareholders' meetings.

The new KCC also allows restrictions on transfer of shares. Under the new $\mathrm{KCC}$, the Articles of Incorporation of stock corporations can restrict a transfer of shares by making it subject to the approval of the board. ${ }^{47}$ An appraisal remedy will be available to the affected shareholders. This change has significant implications for change of control of the firms with few shareholders, including joint-venture enterprises. ${ }^{48}$ The powers of the board under the Articles of Incorporation to restrict a share transfer provide the incumbent management with a strong tool to protect its control.

Parallel with the pro-management changes to the $\mathrm{KCC}$, a statutory auditor's tenure is extended from two to three years ${ }^{49}$ to safeguard its independence and supervisory functions. Also, the statutory auditor's legal power has greatly been enhanced through, inter alia, the new entitlement to call an extraordinary shareholders' meeting. ${ }^{50}$ As before, for the purpose of electing statutory auditors, a shareholder holding more than three percent of the outstanding shares having voting rights may not exercise voting rights with respect to shares held in excess of three percent. ${ }^{51}$

The KCC also mandates appraisal rights for dissenters in mergers or sales of businesses. ${ }^{52}$ The appraisal remedy for dissenting shareholders in mergers or sales of businesses was not unknown in Korea; the KSEA also provides procedural rules for expressal rights, along with a valuation method. ${ }^{53}$ There have been several instances where proposed merger transactions were aborted due to the drain on a company's liquidity. Of course, whether those deals would have been value increasing ones cannot ultimately be known. ${ }^{54}$ Dissenting share-

45. See id.

46. The failure to meet those requirements does not invalidate the meetings held, but prevents the relevant resolutions from being adopted; normal resolutions require the vote of at least twentyfive percent of all of the issued and outstanding shares in the company voting therefor. Special resolutions for central business decisions such as mergers require the vote of at least one-third of all of the issued and outstanding shares in the company voting therefor. The Articles of Incorporation are allowed to impose more restrictive requirements than the ones stipulated in Art. 368 of the KCC, but not less restrictive ones.

47. See Art. 335 of the KCC.

48. It is common practice in Korea for a joint-venture agreement to have express provision prohibiting any transfer of shares without prior consent of the other partner. Although, under such contractual arrangements, no cause of action is available against the company itself, the Seoul District Court, in its decision of Nov. 20,1997, 97pa7454, has recently ruled that shareholders who acquired shares in violation of such a prohibition are not entitled to call a shareholders' meeting.

49. See Art. 410 of the KCC.

50. See Art. $412-3$ of the KCC.

51. See Art. 409 (2) of the KCC. Art. 409 (3) of the KCC allows more restrictive requirements in a charter provision. The three percent-limit rule applies to discharge of statutory auditors of listed companies without cause. See Art. 191-11 (1) of the KSEA.

52. See Art. 374-2 with Art. 530 (2) of the KCC.

53. See Art. 191 of the KSEA.

54. Cf. Bayless Manning, The Shareholder's Appraisal Remedy: An Essay for Frank Coker, 72 YALE L. J. 223, 234-36 (1962) (criticizing appraisal as a possible drain on a company's liquidity 
holders in the deals reportedly were disappointed by proposed merger ratios. As they were institutional investors with significant shareholdings, they successfully blocked the transaction by announcing their intent to exercise their appraisal rights in advance. ${ }^{55}$ Nevertheless, while approval rights can be a powerful tool of shareholders, there is little empirical evidence showing that the appraisal remedy systematically checks Korean managers' breaches of fiduciary duty. ${ }^{56}$

The KCC was amended again in October 1998 to comply with the IMFmandated program. The amendments deal exclusively with the section governing stock corporations and have a direct impact on corporate governance and restructuring. The official comments to the amendments state that they are intended to support corporate restructuring and enhance managerial accountability and transparency through efficient monitoring.

The KCC has introduced the concept of directors' fiduciary duty of loyalty into the statute. ${ }^{57}$ It has long been recognized that the director of a stock corporation is under such a duty even though the $\mathrm{KCC}$ did not explicitly provide for it. The current version of the KCC now imposes this statutory obligation on directors of stock corporations. Further, the current $\mathrm{KCC}$ also holds de facto directors liable for damages under certain circumstances. ${ }^{58}$ It has been a widespread practice in Korea that the ultimate control over large firms lies in the hands of "owners" who do not hold any official corporate directorship. The KCC enhances managerial accountability by also holding them liable for mismanagement and misconduct. The status of minority shareholders is promoted through the introduction of a shareholder proposal right. ${ }^{59}$ The KCC also introduces cumulative voting. ${ }^{60}$ This is a quasi-default rule in the KCC

that may deter value-increasing deals); Frank H. Easterbrook and Daniel R. Fischel, The EcoNOMIC STRUCTURE OF CORPORATE LAW 145-49 (1991) (viewing appraisal as a protective mechanism for shareholders from value-decreasing transactions).

55. See KS Kim, Chaebol and Corporate Governance, supra note 7, at 166-7. It has been reported that dissenting shareholders of 25 listed Korean companies have exercised their appraisal rights in merger or sale of business transactions for a total of 4.91 million shares in 1997. JoongANG ILBo, Dec. 30, 1997, at 30.

56. Cf. Victor Brudney and Marvin Chirelstein, Fair Shares in Mergers and Take-Overs, 88 HARV. L. Rev. 297, 304-07 (1974) (arguing that the appraisal remedy has limited power as a check on managers' breaches of fiduciary duty because of the rational apathy and free-rider problems).

57. See Art. 382-3 of the KCC.

58. See Art. $401-2$ of the KCC.

59. See Art. 363-2 of the KCC.

60. See Art. 382-2 of the KCC. As Art. 369 (1) of the KCC (accepting the one share, one vote principle) is understood to be a mandatory rule, cumulative voting was not allowed. However, I argued elsewhere that Art. 369 (1) of the KCC can be interpreted as non-mandatory, referring to criteria developed in Jeffrey N. Gordon, The Mandatory Structure of Corporate Law, 89 Colum. L. Rev. 1549 (1989). See Hwa-Jin Kim, M\&A-Wa Kyongyongkwon [M\&A and Corporate ConTROL] ch. 6 (3rd ed. 1999) (hereinafter Kim, [M\&A AND CoRPORATE CONTROL]). Accordingly, cumulative voting could be adopted by charter provision. For questions of voting in emerging economies, see generally Black \& Kraakman, supra note 4, at 1945-52. Black \& Kraakman report that straight voting is the default rule in most emerging market jurisdictions they have studied. See $i d$, at 1948, note 73. For an account of the U.S. laws, see Jeffrey N. Gordon, Institutions as Relational Investors: A New Look at Cumulative Voting, 94 Colum. L. Rev. 124 (1994). Many Korean corporate law scholars recognized the value of cumulative voting in protecting minority shareholders' 
as it can be ruled out by charter provisions and made subject to shareholders' claims. ${ }^{61}$

\section{B. A New Focus on Outside Directors}

As mentioned above, Korean corporate boards are nominal organizations under the direct control of controlling shareholders in most cases. The boards of Korean firms are regularly comprised of officer-directors without the participation of outside, independent directors. Thus, the role of the board in corporate governance is minimal in Korean corporations. This is also related in part to the fact that in Korea, corporations' directors do not regularly face lawsuits for breaches of fiduciary duties.

The function of corporate boards in improving corporate governance has recently become an important point of public concern in Korea. ${ }^{62}$ It is understood that public opinion supports the concept of active independent board members checking the controlling shareholder-managers and officer-directors. The firms themselves also have slowly realized the value of having efficient boards. Beginning in 1996, the so-called "outside director system" was adopted by several large firms including the Hyundai Group. ${ }^{63}$ However, the new trend focusing on the board and outside directors is closely related to the Chaebolpolicy. The Korean government sees an effective policy tool in the outside director system for its role in separating ownership and control of large public companies. The IMF also has required the Korean government to enhance the managerial accountability of Korean firms through outside directors. Accordingly, the Korean government has made it mandatory for listed companies to have a board with a ratio of three officer-directors to one outside director. The listing rule of the Korea Stock Exchange was amended in February 1998 to enforce this policy. ${ }^{64}$

The Korean Banking Act has introduced a system under which non-officer directors shall hold the majority position on corporate boards. It has been followed by the Law for Structural Improvement and Privatization of State Enterprises, promulgated in August 1997 and put into force on October 1, 1997. ${ }^{65}$ This law places a ceiling of seven percent on individual ownership of shares in

interest. See, e.g., Dong-Yoon Chung, Hoeshabup [The Law of Corporations] 363 (4th ed. 1996).

61. The new KCC has also introduced the short-form merger and the small-scale merger. In the former, the subsidiary by more than 90 percent shareholding, can be merged into the parent without the approval of the shareholders' meeting. See Art. 527-2 (1) of the KCC. In the latter, no approval of the shareholders' meeting of the surviving firm is required if the number of shares to be issued upon a merger amounts to less than five percent of the outstanding shares of the surviving firm. See Art. 527-3 (1) of the KCC. The corporate division also has been introduced in the new KCC. See Art. 530-2 through Art. 530-12 of the KCC.

62. See opinion of Kwang-Sun Chung, Han-Guk Kyongue Shinmin, Sept. 30, 1997, at 10 (arguing for "corporate governance revolution" in Korea).

63. See Han-Guk KyongJe Shinmun, Jan. 19, 1998, at 10 (reporting Hyundai Group's positive experience).

64. See Art. 48-5 of the Listing Rule of the Korea Stock Exchange.

65. See Law for Structural Improvement and Privatization of State Enterprises, Art. 5 (2) [hereinafter the Law]. This Law applies to the four giant state-invested enterprises that are planned 
newly privatized state-owned enterprises. According to the official comment to this law, it is intended to enhance efficiency and accountability of professional managers. ${ }^{66}$

\section{The Establishment of the Secondary Segment of the Korean Securities Market}

The KOSDAQ was launched on July 1, 1996. This secondary segment of the Korean securities market was established mainly to support the financing efforts of new ventures and small businesses. As of November 1997, some 350 firms, including seventy-seven venture companies, were enrolled at the KOSDAQ. ${ }^{67}$ The favorable tax treatment for securities traded on the KOSDAQ is expected to induce large numbers of investors, including foreign investors, ${ }^{68}$ to invest in venture firms specializing in the high-tech and biotechnology areas. However, the KOSDAQ imposes the strict requirements of ownership dispersion for the firms enrolled. For a venture firm to be enrolled in the KOSDAQ, more than twenty percent of its issued and outstanding shares must be held by more than 100 minority shareholders. ${ }^{69}$

Korea's efforts to replicate the U.S.'s success in developing a strong venture capital industry exemplify its recognition that its current model of corporate governance and financial market fails to support newer and smaller companies. However, like some European countries, ${ }^{70}$ Korea may not be successful in developing the institutional infrastructure necessary to support a venture capital market, unless it also introduces some complimentary institutions that are present in the U.S. ${ }^{71}$ Merely creating a stock market in a system lacking complimentary institutions will not be sufficient to provide the necessary conditions for an active venture capital industry. ${ }^{72}$

to be privatized, i.e., Korea Tobacco \& Ginseng Corporation, Korea Telecom, Korea Gas Corporation, and Korea Heavy Industries \& Construction Company. See Art. 2 of the Law.

66. To this end, more restrictive charter provisions are allowed. See Art. 18 (1) of the Law. The Korean government couldn't live up to its official promise to select a foreign professional manager as CEO of one of the four firms. See Foreign CEO Plan at State Firms Fails, KorEa HeRALD, Dec. 10, 1997, at 12.

67. See Foreigners Allowed to Invest in KOSDAQ Venture Companies, KoREA HeRALD, Nov. 14, 1997, at 12 .

68. See id.

69. See Art. 4 (1) No.3 of the KOSDAQ Rule.

70. For an overview of start-up financing in European countries, see Arndt Stengel and Joseph W. Marx, The Financing of Start-up Companies (General Report for AIJA Annual Congress 1997).

71. Such complimentary institutions are venture capital organizations, investment bankers, and a supply of entrepreneurs. Gilson, Globalizing Corporate Governance, supra note 1, at 12-13. See also Curtis J. Milhaupt, The Market for Innovation in the United States and Japan: Venture Capital and the Comparative Corporate Governance Debate, 91 Nw. U. L. Rev. 865, 879-94 (1997) (singling out five traits of the institutional environment that contribute to the success of the U.S. venture capital market: "the existence of large, independent sources of venture capital funding; liquidity; highly developed legal and contractual incentive structures; labor mobility; and risk tolerance").

72. Gilson, Globalizing Corporate Governance, supra note 1, at 12. 


\section{Cultivating Markets for Corporate Control in Korea ${ }^{73}$}

The recent hostile takeover cases in Korea exemplify some of the problems of Korean corporate governance arising from changes in Korean capital markets. They also received extensive publicity, due largely to the departure they represented from generally staid inter-corporate relations in Korea. Under the old law, there was a practical ban on hostile takeovers, which was circumvented in many cases by a loophole for certain shareholding vehicles. This ban, along with related restrictions, was lifted on April 1, 1997, and should result in a greater increase in merger and acquisition activity. In 1997 alone, eleven tender offers were launched in the market, some of them hostile. Furthermore, as will be discussed below, the lifting of the ban on hostile takeovers also applies to foreign investors. As a result, there should be an increase in foreign takeovers of Korean firms.

\section{The Current Situation}

The Korean business community has increasingly accepted mergers and acquisitions (M\&A) as a viable strategic option for external growth and restructuring. ${ }^{74}$ The Korean government also understands that M\&A represents a useful policy tool in industrial restructuring. Although there have been no serious discussions yet in Korea about the beneficial effects of takeovers in terms of shareholder wealth, ${ }^{75}$ the role of the market in disciplining poorly performing management ${ }^{76}$ is slowly being recognized by the Korean academic and legal communities.

73. For law and practice of corporate acquisitions in Korea, see generally Kim, [M\&A AND Corporate Control], supra note 60.

74. See Firms Urge Special Law on Restructuring, Korea Herald, Nov. 7, 1997, at 12 (reporting that in a poll of 315 large firms about problems in industrial restructuring, about 60 percent of respondents cited the current complex procedure for $M \& A s$ as the biggest hurdle to their restructuring efforts).

75. For studies of the evidence that takeovers are beneficial to shareholders and society, see Easterbrook and Fischel, supra note 54, at 190-205; Richard Roll, Empirical Evidence on Takeover Activity and Shareholder Wealth, in KNIGHTS, RAIDERS AND TARGETS: The IMPACt OF THE HostILE TAKEOVER, ch.14 (John C. Coffee et al. eds. 1988). See also McGinty, supra note 22, at 992, n. 17 (informative summaries of literature). As takeovers generally benefited society, takeover defenses and anti-takeover laws of the individual States of the U.S. are viewed as detrimental to the societal wealth maximization. See, e.g., Gregg A. Jarrell et al., The Market for Corporate Control: The Empirical Evidence Since 1980, 2 J. Econ. Persp. 49 (1988); Jonathan M. Karpoff \& Paul H. Malatesta, The Wealth Effects of Second-Generation State Takeover Legislation, 25 J. FIN. Econ. 291 (1989).

76. For the earliest account, see Henry G. Manne, Mergers and the Market for Corporate Control, 73 J. Pol. Econ. 110 (1965) (pointing out, for the first time, the importance of the takeover threat in inducing managers to be concerned about shareholders' interests). See also Frank H. Easterbrook and Daniel R. Fischel, The Proper Role of a Target's Management in Responding to a Tender Offer, 94 HARv. L. REv. 1161, $1165-74$ (1981) (emphasizing the role of tender offers in disciplining managers); Joseph A. Grundfest, Just Vote No: A Minimalist Strategy for Dealing with the Barbarians Inside the Gates, 45 STAN. L. REv. 857, 873-901 (1993) (collection of anecdotal evidence indicating the potential for shareholder gains from replacing incumbent management); Ronald J. Gilson \& Bernard S. Black, The Law and Finance of Corporate Acquisitions, ch. 10 (2nd ed. 1995) (selected empirical studies). However, as American managers have successfully developed effective takeover defenses and convinced state legislatures to enact anti-takeover laws, takeovers' disciplinary threat to management has significantly weakened. Discussions about alterna- 
The internationalization of Korean capital markets is likely to increase takeovers and foreign ownership of listed companies. ${ }^{77}$ Foreign firms' acquisition of undervalued Korean firms with weak local currency is expected to increase, in particular during the industrial restructuring period guided by the IMF. This activity, along with the abolished ownership restriction, will facilitate the growth of the M\&A market in Korea. An increased number of diverse M\&A transactions has already been reported among listed companies since 1995. Tender offers, once viewed as a remote foreign tool, have increased recently, although usually in their most basic form. To be sure, most deals occurring in Korea so far have been friendly and consummated with the aim of restructuring the operational functions of large businesses. However, the active M\&A market is expected to eventually develop a market for corporate control in Korea, which should have a wide range of impacts within Korea.

The arguably emerging market for corporate control in Korea has already impacted Korean financial markets. For instance, after the highly-publicized proxy battle for Hanwha Merchant Bank in early 1997, where the incumbent management successfully preserved control by secretly issuing convertible bonds to friendly firms, ${ }^{78}$ many Korean companies privately placed convertible bonds or bonds with warrants in huge volumes to increase friendly shareholding. As the negative impact of this practice on the market reached the critical point in March $1997,{ }^{79}$ the Korean government introduced some restrictions on certain market-distorting activities. The increase of takeover activities in Korea will continuously encourage concerned firms to search for effective takeover defensive tactics, including restructuring of their capital structure. ${ }^{80}$ The financial institutions in Korea may also be interested in entering into the lucrative busi-

tive mechanism are ongoing in the U.S., and increasingly focused on the new shareholder activism by institutional investors, independent directors and foreign governance institutions.

77. See Art. 5 of the Korean Financial Supervisory Commission Rule on Securities Transaction by Foreigners.

78. The Seoul District Court, in its decision of Feb. 6, 1997, 97kahap1 18, dismissed a motion to enjoin exercising voting rights attached to the converted shares in question, holding that issuing convertible bonds in the case was legitimate and legal. The Court emphasized the importance of liquidity protection for the shares. The Seoul High Court, in its decision of May 13, 1997, 97ra36, upheld the decision of first instance, but held that the convertible bonds issued in question were invalid for illegality involved in the issuing process. For the text of both decisions, see Kim, [M\&A AND CORPORATE CONTROL], supra note 60, at 150-160. Such cases became moot as the merchant bank closed in February 1998.

79. In January, February, and March 1997, 46 companies issued convertible bonds and 22 companies issued bonds with warrants, all through private placement. The volume totaled 1.22 trillion won. The decision of the Seoul District Court in the Hanwha Merchant Bank Case was handed down on Feb. 6, 1997, and the 10 percent ownership restriction was abolished from April 1, 1997. See Kim, [M\&A AND CORPORATE CONTROL], supra note 60, at 148-149.

80. The placement of new common shares or equity-related debt instruments on friendly hands is the most widely used, and controversial, takeover defensive tactic in Korea. Under Korean law, poison pill, in its forms prevailing in the U.S., is not allowed. Defensive stock repurchases have become fairly popular, but the 33.3 percent limit and requirement of purchase through securities exchange have been restraining factors until the recent abolishment of such limitations. Staggered boards, limiting the number of board members, proxy campaign and lock-ups are also widely used defensive tactics in Korea. For takeover defensive tactics available under Korean laws, see generally Kim, [M\&A AND CoRporate ConTroL], supra note 60, chs. 5, 6-7. 
ness of takeover finance. The Korean government will focus more intensively than before on financial institutions regulation, a fundamental reform which has long been overdue.

\section{The New Regulatory Framework}

Under the old KSEA, there was a basic ceiling of ten percent for individual ownership of listed companies. ${ }^{81}$ The rule generally applied to any shareholders except the founder of the company. The reasoning was to convince the controlling shareholders (founders) to let their firms go public without the fear of losing corporate control. Indeed, this policy has greatly contributed in expediting the building of Korean capital markets. This restriction, however, made less sense as the size of the Korean stock market increased. The rapid growth achieved by Korean firms compelled them to go public and, as a consequence, the incentive rule has become unnecessary. It only distorted the ordinary functioning of the capital market by imposing an anomalous barrier in securities trading. The new KSEA has abolished the restrictive rule.

Under the new KSEA, tender offers are the central mechanism for shifts in corporate control. Although some tender offers launched so far in Korea have been criticized for their questionable purposes, ${ }^{82}$ it is widely accepted that the tender offer is the most appropriate mechanism for protection of minority shareholders from control abuses. Now, a securities transaction involving the transfer of more than a five percent (5\%) shareholding out of the Korea Stock Exchange or KOSDAQ is required basically through tender offers. ${ }^{83}$

The old KSEA had introduced the obligation to make a bid. Any person aiming to acquire securities, which, when added to any existing holdings, gave him voting rights in a company totaling more than twenty-five percent, was obliged to make a bid by tender offer to acquire more than fifty percent of the

81. See Art. 200 of the old KSEA.

82. Some tender offers made at a price lower than market price of the shares have been successful because the tendering shareholders have already committed to tender by certain contractual arrangement with the offerer. Those shareholders were either nominal shareholders who bought the shares on offer with a simple fee arrangement or real shareholders who bought the shares upon offerer's contractual commitment to buy the shares with a fixed premium. In latter cases, agreement on voting was common. Also, there were instances where the potential acquirer entered into secret share purchase agreements with a third party and bought shares of the target in reliance on the agreement before launching a tender offer. This tactic has been used mainly to avoid the requirement of the disclosure rule. Currently, there is one reported case in Korea from which a lawsuit for damages has developed in relation to the breach of such contractual arrangements. See Kim, [M\&A AND CoRporate CONTROL], supra note 60 , at 85 , note 6 . On the other hand, the recent high-profile tender offer for shares in Lady Furniture turned out to be part of a fraudulent scheme. This incident has raised doubt about the efficiency of current regulation. See Han-Guk Kyongue Shinmun, Nov. 26, 1997, at 4 .

83. See Art. 21 (1) of the KSEA. There existed a requirement for tender offer price under the pre-1998 version rule: the bid shall be made at the highest price an individual paid for any of the target company's shares within twelve months or the market price of the target company's shares on the previous day of his or her filing of application with the authority, whichever is higher (Art. 13-3 of Enforcement Decree to the pre-1998 version KSEA). Such requirement was abolished by the February 1998 revision of the rule. 
issued and outstanding voting shares of that company. ${ }^{84}$ The tender offers for 24.99 percent of Ssangyong Paper and Hankuk Electric Glass, both in November 1997, were made under the rule. This rule modified from the British City Code on Takeovers and Mergers ${ }^{85}$ and the proposed European Community 13th Directive on Company Law, ${ }^{86}$ was widely criticized for facilitating the concentration of economic power and setting an unreasonably high burden on valueincreasing corporate acquisitions. The February 1998 amendments to the KSEA abolished this requirement.

The new KSEA has also refined "the early warning system," or five percent disclosure rule. ${ }^{87}$ Now, the obligation to report is expanded to such equityrelated debt instruments as convertible bonds, bonds with warrants, and exchangeable bonds. ${ }^{88}$ The KSEA has widened the circle of obliged persons by introducing the concept of "holders on common purposes", 89 adopting the practical approach of the U.S. Williams Act. ${ }^{90}$

\section{The Emergence of the Market for Corporate Control}

The friendly acquisition of Korean firms by foreign investors was allowed, with some qualifications, under the (then) Law on Foreign Investment and Foreign Capital Inducement, ${ }^{91}$ effective from February 1, 1997. However, direct hostile acquisition of Korean firms by foreign investors without the approval of incumbent management was not possible until recently. Also, the ceiling on individual foreign ownership in listed companies practically prevented foreigners from acquiring control of listed Korean firms. Nevertheless, the opening of the domestic market for foreign control has become a reality since the abolition of these restrictions.

It has been discussed whether Korea should open the domestic market for corporate control to promote competitiveness, including that of financial institutions. The proponents' view ${ }^{92}$ has recently received much support. The issue, however, was not totally new to Korea. Since late 1996, Korea has participated

84. See Art. 21 (2) of the pre-1998 version KSEA with Art. 11-2 of Enforcement Decree to the KSEA

85. Panel on Takeovers and Mergers, The City Code on Takeovers and Mergers and the Rules Governing Substantial Acquisitions of Shares (1993). See Deborah A. DeMott, Current Issues in Tender Offer Regulation: Lessons from the British, 58 N.Y.U. L. REv. 945 (1983).

86. Commission Proposal for a Thirteenth Directive on Company Law Concerning Takeover and Other General Bids, 1990 O. J. (C 38) 41, 44. See Klaus J. Hopt, European Takeover Regulation: Barriers to and Problems of Harmonizing Takeover Law in the European Community, in European TAKeOvers - Law and Practice ch. 6 (Klaus J. Hopt \& Eddy Wymeersch eds. 1992); Jeffrey P. Greenbaum, Tender Offers in the European Community: The Playing Field Shrinks, 22 VAND. J. Transnat'L L. 923 (1989); Nathalie Basaldua, Towards the Harmonization of EC-Member States' Regulations on Takeover Bids: The Proposal for a Thirteenth Council Directive on Company Law, 9 NW. J. INT'L. \& Bus. 487 (1989).

87. See Art. 200-2 (1) of the KSEA.

88. See Art. 10 of Enforcement Decree to the KSEA.

89. See id. Art. 10-3 (4).

90. For the concept of a "group" under Section 13(d) of the Williams Act, see Robert Charles Clark, Corporate Law 555-57 (1986).

91. See Art. 8-2 Foreign Investment Promotion Act, effective from Nov. 17, 1998.

92. See, e.g., Seong C. Gweon, Fighting for What?, Korea Herald, Nov. 19, 1997, at 8. 
in negotiations on the Multilateral Agreement on Investments (MAI) sponsored by the OECD. The MAI would allow hostile takeovers by foreign investors in Korea as all parties to the agreement would be required to give foreigners the same treatment as their domestic counterparts. Even though most Korean companies wanted a delay in foreign investors' hostile takeover activities in Korea, it was unclear if other members of the OECD would accept such a position. The major concern of Korean companies was the lack of a level playing field for both domestic and foreign firms. The opening of the domestic market for foreign control in Korea, however, has become a reality since the abolition of restrictions on foreign ownership discussed previously.

It is anticipated that foreigners' participatory investments in large Korean companies will increase due to the weak Korean currency and undervalued stock prices. ${ }^{93}$ Korean firms themselves have started to seek foreign partners for global strategic alliances to meet the challenges from the whole new business and regulatory environment. ${ }^{94}$ It is widely recognized that opening of the Korean market for corporate acquisitions and strategic alliances to foreign firms will not be complete and effective without enhanced transparency of "consolidated" corporate financial statements made by generally accepted international accounting practices. ${ }^{95}$ General deregulation on business activities, improvement of labor market flexibility, free international transfer of capital, and improvement of administrative infrastructure in the public services sector are also necessary. For the improvement of labor market flexibility, which was a key condition of the IMF bailout package, ${ }^{96}$ the Basic Labor Law has been amended to allow companies to lay off workers when they face an "emergency situation." 97 According to the Basic Labor Law, sale of businesses or mergers and acquisitions to avoid financial trouble shall justify layoffs. ${ }^{98}$ The new Law Concerning Foreign Ownership of Land, effective on June 26, 1998, has abolished various restrictions on the foreign ownership of land to promote foreign invest-

93. See Listed Firms' Combined Stocks Worth Less Than World's Top 70th Company, KoreA Herald, Dec. 27, 1997, at 11 (reporting that, as of Dec. 24, 1997, the market value of the total amount of stocks listed on the Korea Stock Exchange stood at $\$ 33.9$ billion, which was less than that of the Dutch ING).

94. See Steve Glain \& Michael Schuman, Seoul Looks to Foreigners for a Lifeline, AsIAN Wall St. J., Dec. 24, 1997, at 1, 5; Korea's Woes Don't Deter Some Multinational Firms, Asian WaLl St. J., Feb. 16, 1998, at 3; Mark Clifford et al., Age of the Deal, Bus. WeEk (Asian Edition), March 2, 1998, at 16-20; Martin du Bois, Buyer's Market: As Asia's Going Gets Rough, Europe Inc. Goes Asset Shopping, Wall St. J. EUROPE, May 11, 1998, at 1, 11.

95. See Chaebols Test Waters for Transparency, Korea Herald, Jan. 6, 1998, at 10 (reporting that the total sales figure of a large group could be slashed by as much as $30 \%$ in consolidated financial statements). See also Korea Financial Supervisory Commission \& Korea Securities and Futures Commission, Reform of Accounting Standards in Korea, Dec. 11, 1998 (visited March 6, 1999) <http://www.fsc.go.kr/kfsc/new_e_index $1 . \mathrm{htm}>$ (claiming that "financial accounting standards are newly born in Korea inconsistent with international best practices").

96. See No. 38 of the Korea-IMF Memorandum, supra note 27.

97. See Michael Schuman, Korean Layoffs Pact Shows Union's Change in Stance, AstaN Wall St. J., Feb. 9, 1998, at 3.

98. See Art. 31 (1) of the Law. The Law calls for management to do its best to avoid layoffs (see id. Art. 31 [2]) and give 60 days notice before dismissing workers (see id. Art. 31 [3]). Employers are also required to try to rehire dismissed workers first if business improves (see id. Art. 312). 
ments in Korea. Now, acquisition of land by foreigners is not subject to government approval except for certain cases concerning military policy, environmental protection, and landmark protection. ${ }^{99}$

\section{III.}

\section{Corporate Governance and Banks in Korea}

\section{A. A Need for Change of the Ownership Structure of Banks?}

One of the most contentious issues in Korea currently is corporate governance of banks. It is widely believed that many failures in Korea have been caused by bank managers' breach of their fiduciary duties. This widespread "directed lending" under governmental influence produced a huge volume of non-performing loans to highly leveraged large businesses. ${ }^{100}$ When directed lending was the common practice, no effective monitoring system was available. As those borrower firms failed, the lender banks also lost substantial sums of money, which in turn led to the chaotic situation of the Korean financial markets. This arguably could have been prevented by closer monitoring of bank managers.

One solution to this problem is to allow non-financial firms-including those belonging to the Chaebols - to control commercial banks. This could be achieved by lessening ownership restrictions on bank shares. A controlling shareholder with a private business background might be able to improve the efficiency and accountability of bank management. ${ }^{101}$ The proponents of lesser restriction on bank ownership argue that a concentration of bank ownership may be helpful in overhauling the financial system in Korea.

Others have argued that if the restrictions on the ownership of bank shares were relaxed, Korean banks would easily become the treasury of some Chaebols. ${ }^{102}$ This could lead to mismanagement of those shareholder-firms because they would feel unjustifiably secure in their financing efforts. Proponents of ownership restriction argue that efficiency and accountability can be achieved by enhancing bank supervisory systems and/or introducing well-functioning outside directors. Another approach is to promote bank mergers. The Korean government has provided a separate legal regime to promote mergers of banks under the theory that such mergers increase competitiveness through enhanced operational efficiency and financial soundness. The Korean Banking Act also has been changed to introduce the outside director system.

99. Still, there are notification requirements. See Art. 4 (1) and Art. 5 of the Law.

100. See Roy Ramos \& Chunsoo Lim, Bailout or Not, Korea Needs Change, Asian Wall St. J., Dec. 1, 1997 at 20 (estimating that bad debts amount to $\$ 110$ billion which would be more than the entire annual economic output of Singapore, Malaysia or the Philippines).

101. See, e.g., Editorial, Han-Guk Kyongue Shinmun, June 26, 1997, at 11; Opinion of ByungHo Kang, Maeil Kyongue, Oct. 4, 1996, at 5; Editorial, Han-Guk Kyongue Shinmun, Jan. 17, 1998 , at 5 .

102. See, e.g., Opinion of Un-Chan Jung, Chosun Ilbo, July 2, 1997, at 5 and Chung-Lim Choi, Chosun ILbo, April 3, 1997, at 5. 
Until recently, Korea maintained a basic ceiling of four percent for bank ownership. ${ }^{103}$ The ceiling on bank ownership, however, has been weakened by the new Korean Banking Act, ${ }^{104}$ promulgated on January 13, 1998, and partially amended again in February and May 1998 and January 1999. The Korean Banking Act implements the agreement of the Korean government with the IMF. Although the ceiling still formally remains, the acquisition of bank shares of more than four percent or fifteen percent may be done by the approval of the Korean government. Since the new regulation is structured in a way to favor foreign investors, it is now being discussed whether the basics should also be changed. It remains to be seen whether the IMF-mandated change of ownership structure of Korean banks will prove efficient. However, it is clear that the improvement of governance of Korean banks will also continuously be sought through functional approaches in line with such efforts for non-banking corporations.

What are the possible lessons from comparative corporate governance in terms of bank managers' accountability? Should Korea continue the efforts toward functional improvement of bank governance, even after the internationally mandated formal changes have been implemented? The answer is clearly yes. The efficiency and soundness of a banking system are too complicated to be answered by any single approach. So is the accountability of bank managers. Strict monitoring may prevent the bank managers from self-dealing and engaging in other misconduct. Nevertheless, strict monitoring may also cause conservative lending practices, which may be difficult to differentiate from selfentrenchment. Korean banks need both the changed ownership structure and the private, business-oriented, managerial minds "supported" by a well-functioning board.

\section{B. Outside Directors Again}

Under the new Korean Banking Act, the board of directors of Korean banks shall have more outside directors than officer-directors. ${ }^{105}$ The outside directors are to be appointed among the candidates recommended by representatives of shareholders and the board at the elective ratio of seven to three. ${ }^{106}$ The president of a bank shall be elected by an affirmative vote of two-thirds or more of the outside directors. ${ }^{107}$

This new approach to bank corporate governance has been strongly criticized for not being realistic. As in other economies, even those highly efficient economies such as Germany ${ }^{108}$ and the U.S., ${ }^{109}$ the "outside" directors often

103. See Art. 17-3 of the former Banking Act. This restriction did not apply to the shareholding in joint venture banks and local banks with restricted regional business areas. To the local banks, the ownership ceiling of 15 percent applied. See Art. 17-3 (1) of the former Banking Act.

104. See Arts. 15, 16 and 17 of the Act.

105. Art. 22 (2) of the Act.

106. See Art. 22 (3) through (9) of the Act.

107. Id. Art. 24.

108. For the failure of the German two-tier system, see Guenter H. Roth, Supervision of Corporate Management: The "Outside" Director and the German Experience, 51 N. C. L. REv. 1369 , 
turn out to be not "independent" enough to contribute to managerial accountability. The complicated recommendation and appointment procedure has only made the bankers' jobs harder, with little to show for such troubles. It is, however, interesting to see that the first ever effort to rationalize corporate boards in Korea has been made by the Banking Act. The model suggested by the Banking Act has also been adopted by some newly privatized state-owned enterprises as described earlier.

\section{Bank Mergers and Acquisitions}

Although the M\&A boom among large banks abroad ${ }^{110}$ was well known in Korea, the concept of bank mergers has not been widely accepted until recently. This is related to the traditional view of financial institutions as quasi-public organizations rather than private business entities. It also clearly illustrates the path dependent limits of the Korean economy as it exists today. However, the argument that rising international standards and increasing competition among banks in global markets should be met by promoting mergers of banks has recently become very compelling and persuasive. Thus, in December 1996, the Korean government promulgated the Law for Structural Improvement of Financial Industry to facilitate mergers of Korean banks. It contains various provisions easing mergers of financial institutions, including favorable tax treatment for the merger transaction, and regulating the liquidation and reorganization process for troubled financial institutions. However, the voluntary mergers of banks as envisaged were still not feasible due largely to potential problems of layoffs that would inevitably follow any merger of banks in Korea.

The recent restructuring efforts guided by the IMF have changed the situation. As the ownership ceiling on bank shares and foreign ownership restriction

1378-82 (1973). Two separate and distinct bodies, i.e., the management board (Vorstand) and the supervisory board (Aufsichtsrat), govern the German stock corporation (Aktiengesellschaft). Direct control of corporate affairs is vested in the former which, in turn, is supervised by the latter. It is argued that the management boards of German corporations succeed in usurping the controlling function of the supervisory boards. See Josef Esser, Bank Power in West Germany Revised, 13 West Eur. Politics 17, 27 (1990). However, the two-tier system has been spreading throughout Europe in recent years and is presently reflected in the European Union's major legislative proposals relating to company law. See Kim, supra note 4, at 379 n. 40.

109. For recent efforts addressing the governance role of the board with increased independence of outside directors, see, e.g., The Business Roundtable, Corporate Governance and American Competitiveness, 46 Bus. Law. 241 (1990); Ronald J. Gilson and Reinier Kraakman, Reinventing the Outside Director: An Agenda for Institutional Investors, 43 STAN. L. Rev, 863 (1991) (advocating increasing the dependence of outside directors on shareholders). But see, Victor Brudney, The Independent Director - Heavenly City or Potemkin Village?, 95 Harv. L. Rev. 597, 607-39 (1982) (skeptical view). For positive practical cases, see Grundfest, supra note 76, at 880-900. See also John W. Byrd and Kent A. Hickman, Do Outside Directors Monitor Managers?: Evidence from Tender Offer Bids, 32 J. Fin. Econ. 195, 201-05 (1992) (recognizing outside directors' role in improving managerial performance); John A. Byrne et al., The Best BOA, Bus. WeEk, Dec. 8, 1997, at 46-52.

110. See, e.g., Thane Peterson et al., The Big One, Bus. WEeK, Dec. 22, 1997, at 26-29 (merger of UBS and SBC in Switzerland); Michael Siconolfi, Citicorp Merger with Travelers Signals New Era, Asian Wall. St. J., April 7, 1998, at 1, 2; Really Big Deal, Asian Wall St. J., April 8, 1998, at 8; Steven Lipin \& Anita Raghavan, BankAmerica, NationsBank to Join in $\$ 60$ Billion Deal, Asian Wall St. J., April 14, 1998, at 1, 26. 
on acquisition of controlling shares of listed firms have been abolished, foreign banks are expected to acquire some Korean financial institutions, including commercial banks. The Korea-IMF Memorandum also provides that the financial sector restructuring could involve "mergers and acquisitions by domestic and foreign institutions"111 and that foreign financial institutions will be allowed "to participate in mergers and acquisitions of domestic financial institutions in a friendly manner and on equal principles." 12 As the first step to honor the commitment, the Korean government agreed with the IMF to privatize to certain U.S. commercial banks the troubled Korea First Bank and Seoul Bank by November 1998. ${ }^{113}$ The January 1998 revision of the Korean Banking Act accommodates, and even promotes, foreign investors' acquisition of Korean banks by allowing them to acquire bank shares without limit with the approval of the Korean government. ${ }^{14}$ On the local level as well, bank mergers are underway as the Korean government seeks to comply with the IMF-mandated program for the restructuring of the financial industry. In June 1998, four troubled local banks have practically been merged into other local banks by relevant rules of the Law for Structural Improvement of Financial Industry. In August and September 1998, some local banks announced their plans for friendly merger with each other, namely, The Commercial Bank of Korea with Hanil Bank; Hana Bank with Boram Bank; and Kookmin Bank with Korea Long Term Credit Bank.

\section{Banks' Participatory Investments}

Contrary to the academic environment in the U.S. and Europe, banks' participatory investments in non-banking and non-financial sectors are not actively discussed in Korea. ${ }^{15}$ At present, the Korean Banking Act limits bank's ownership of non-financial corporations to fifteen percent. ${ }^{116}$ This reflects, in part, the historical reality that Korean banks have exercised far greater influence on their debtor corporations as the creditor. However, such influence does not necessar-

111. See No. 17 of the Korea-IMF Memorandum, supra note 27.

112. Id., Nos. 19 and 31.

113. See Han-Guk Kyongue Shinmun, Feb. 18, 1998, at 4.

114. See Art. 15 (3) of the Act.

115. The most widely studied model for banks' participatory investments is the German model because German law allows banks to hold voting shares of non-banking companies and the German firms under such a system are in fact very competitive in the global market. The literature on German corporate governance in that respect has in the mean time become very rich. See, e.g., Ulrich Immenga, Participatory Investments by Banks: A Structural Problem of the Universal Banking System in Germany, 2 J. Comp. Corp. L. \& Sec. Reg. 29 (1979); Theodor Baums, Corporate Governance in Germany: The Role of the Banks, 40 Ам. J. CoмP. L. 503 (1992); Friedrich K. Kübler, Institutional Owners and Corporate Managers: A German Dilemma, 57 Brook. L. Rev. 97 (1991); Mark J. Roe, Some Differences in Corporate Structure in Germany, Japan, and the United States, 102 Yale L. J. 1927 (1993); Kim, supra note 4; John Cable, Capital Market Information and Industrial Performance: The Role of West German Banks, 95 ECON. J. 118 (1985); Hermann Kallfass, The American Corporation and the Institutional Investor: Are There Lessons from Abroad? The German Experience, 1988 Colum. Bus. L. Rev. 775.

116. See Art. 37 (1) of the Act. 
ily contribute to the improvement of governance of the debtor firms. ${ }^{117}$ Therefore, it is expected that the discussion on banks' participatory investments, in the form of the statutory change on the limits of ownership, will take place as the practical influence of Korean banks on their debtor firms diminishes due to the financial market internationalization.

In such anticipated discussions and studies, Koreans should also take into account the skeptical views of commercial bank involvement in corporate governance. In their recent study, Professors Macey and Miller argue that "proponents of bank involvement not only fail to address the significant costs of the Japanese and German systems of bank-dominated corporate governance, but ignore important benefits of the American system of equity-dominated corporate governance as well."118 In their opinion, bank involvement will not cure the agency problems created by the separation of ownership and control because it carries with it an entirely new set of conflicts between equity claimants and creditors. ${ }^{119}$ It is clear that Korean banks, having realized the importance of controlling the moral hazard of their borrowers, will actively seek the opportunity to participate in the governance of borrowers. Their stake in the borrower firms may even arise through bad debt-to-equity swaps. The Korean Banking Act now allows banks to transfer credits to equity even in such cases where the banks end up with a shareholding of more than fifteen percent. Such an effort, however, may have an adverse impact on the development of the securities market in Korea, which is crucial to the improvement of Korea's financial institutions.

Korean banks should also be aware that the Korean bankruptcy law accepts the principle of equitable subordination in its rather extreme form. Under the typical reorganization plan presented to Korean courts, corporate debts owed to creditors in control are completely forgiven. The Korean Supreme Court interprets the doctrine of equal treatment provided in the Corporate Reorganization $A c t^{120}$ in terms of fairness and equity so that such treatment of creditors in control may be seen as legitimate. ${ }^{121}$

117. However, the Korean banks' influence on the governance of their borrowers is expected to increase through the "Accords for Improvement of Financial Structure" between the banks and large corporate groups. Under the accord, which was initiated by the new Korean government, large corporate groups shall appoint outside directors, cause their subsidiaries to merge, and allow banks to investigate various corporate documents and manufacturing sites. A breach of the accord will cause loan call-offs and call-ins. See Maen Kyongue, Feb. 18, 1998, at 1, 7; Chun Sung-Woo, Banks Seen as Key Players of Corporate Restructuring, Asian WAll St. J., Feb. 21, 1998, at 10.

118. Jonathan R. Macey \& Geoffrey P. Miller, Corporate Governance and Commercial Banking: A Comparative Examination of Germany, Japan, and the United States, 48 StAN. L. REv. 73, 75 (1995).

119. See id. ("Advocates of bank influence also ignore critical differences between the monitoring incentives of equity holders and the monitoring incentives of debt holders. Much of the confusion in the current debate stems from a failure to appreciate the economics of commercial banking in general and of commercial bank lending in particular.")

120. See Art. 229 of the Act.

121. See the Court's decision of July $25,1989,88 \mathrm{ma} 266$. Further, the practice of the Korean judiciary is that once the court approves a reorganization plan, shares held by the controlling shareholder, who is responsible for the insolvency of the firm, shall in principle be redeemed in total. 
IV.

Market Internationalization and Corporate Governance

\section{A. International Regulation of Financial Institutions}

Bank failures, unlike those of non-financial corporations, are minimized by a different kind of safety valve. Their operational soundness and functional efficiency are also guaranteed by the regulation of financial institutions. Parallel with the improvement of corporate governance of Korean banks through structural changes, more attention should be given to the effect of banking regulations. ${ }^{122}$ In particular, due to the rapid increase of Korean banks' activities in international financial markets, international standards for the regulation of financial institutions are expected to exert positive influences on the operation of Korean banks. These standards may enhance the bank managers' accountability.

The Korean government had already introduced the risk-adjusted capital standards recommended by the Bank for International Settlements (BIS) ${ }^{123}$ as a prudential measure to ensure capital adequacy of Korean banks. These requirements came into force at the end of 1995 and all Korean banks are now required to maintain an equity capital position equivalent to at least eight percent as suggested by the BIS. The normative power of the BIS rules has become tremendous in the Korean financial community since the recent involvement of international lending agencies in the restructuring of the Korean financial sector. The BIS rules have been used as an important policy tool for the Korean government in its restructuring efforts for the troubled Korean financial industry, under its agreement with the IMF. The Korea-IMF Memorandum provides first that Korea needs "a strong and transparent financial system which operates free of political interference and according to the rules and practices of the advanced industrial countries." 124 It then makes revocation of merchant banking licenses

122. See generally Office of Bank Supervision of the Bank of Korea, Bank Supervisory System in Korea (May 1997). The Law on Establishment of Financial Supervisory Agency, promulgated on December 31, 1997 with effect from April 1, 1998, has set up an integrated financial supervisory agency in Korea. The new Financial Supervisory Board has resulted from the merging of financial supervisory units so far spread among the Ministry of Finance and Economy and three separate watchdogs, i.e., Office of Bank Supervision, Securities Supervisory Board, and Insurance Supervisory Board. The KSEC's jurisdiction was split and distributed to the Financial Supervisory Board and the Securities and Futures Commission.

123. Committee on Banking Regulations and Supervisory Practices, International Convergence of Capital Measurement and Capital Standards (July 1988) ("the Basle Accord"). See Scott \& Wellons, supra note 16, at 256-323; Duncan E. Alford, Basle Committee International Capital Adequacy Standards: Analysis and Implications for the Banking Industry, 10 Dick. J. INT'L L. 189 (1992); Camille M. Caesar, Capital-Based Regulation and U.S. Banking Reform, 101 Yale L. J. 1525 (1992). See also David Fairlamb, Beyond Capital Adequacy, INst. INv. (International Edition), August 1997, at 22-35. See also <http://www.BIS.org>. The BIS standards are implemented in the European Union through its directives on its own funds and on solvency ratios. $C f$. Council Directive 89/299 of 17 April 1989 on The Own Funds of Credit Institutions, 1989 O. J. (L 124) 16; Council Directive 89/647 of 18 December 1989 on a Solvency Ratio for Credit Institutions, 1989 O. J. (L 386) 14. For a brief account that these rules may change the traditional ownership structure of German corporations, see Kim, supra note 4, at 397-9.

124. See No. 2 of the Korea-IMF Memorandum, supra note 27. 
contingent upon fulfillment of the BIS standards within a certain time frame. ${ }^{125}$ It also envisages severe disciplinary measures to commercial banks, including liquidation, no distribution of dividends and/or freezing management payrolls, again contingent upon rehabilitation plans meeting the BIS standards. ${ }^{126}$ Consequently, Korean commercial banks and other financial institutions have become so sensitive to the BIS standards that they almost blindly called in outstanding loans to borrowers, which has resulted in sudden bankruptcies of affected firms. ${ }^{127}$

It is quite interesting to see that an international standard for banking regulation may contribute to the improvement of soundness of Korean banks that in turn helps improve the governance of Korean banks. The Korean government's participation in the international supervisory system was totally voluntary in a legal sense, but undeniably motivated by the necessity for Korean banks to be recognized as credible partners in global financial markets. This clearly shows that the international financial market may exercise great influence on convergence of national institutions, including corporate governance. ${ }^{128}$ To the extent that such regulations are successful, the use of international banking regulations to improve the banks' governance is an impressive example of functional convergence of corporate governance institutions.

\section{B. Market Internationalization and Institutional Investors' Activism}

In Korea, institutional investors will hold decisive voting blocks in many instances in Korea in the future. At the end of 1996, they held some 31.2 percent of the total shares of listed Korean companies. ${ }^{129}$ Considering the 10.4

125. See id., No. 22.

126. See id., Nos. 23-25.

127. See Massive Corporate Bankruptcy Looming, KOREA Herald, Dec. 29, 1997, at 12 (reporting banks collecting loans to meet BIS standards that would be a crucial criteria for the evaluation of their management and eventually, their M\&As).

128. Professor Van Zandt views that "[i]n some respects, the banking sector is approaching a situation in which it makes sense to talk about the existence of a single international regulatory framework." David E. Van Zandt, The Regulatory and Institutional Conditions for an International Securities Market, 32 VA. J. INT'L L. 47, 76 (1991). It should be noted that, in contrast to the situation in banking regulation, there may be little incentive for nations to introduce an international regulatory framework to improve governance of general corporations. However, the most notable exception may be found in the European Union's efforts to harmonize company laws of the Member States. See generally Steven M. Schneebaum, The Company Law Harmonization Program of the European Community, 14 LAw \& Pol'y INT'L Bus. 293 (1982); Eric Stein, Harmonization of European Company Laws (1971); Alfred F. Conard, The European Alternative to Uniformity in Corporation Laws, 89 Mich. L. Rev. 2150 (1991). The European Union's efforts to harmonize Member States' company laws are also closely related to its financial market integration program. See generally Scott and Wellons, supra note 16, at 324-379; Manning Gilbert Warren, Global Harmonization of Securities Laws: The Achievements of the European Communities, 31 HARV. INT'L L. J. 185 (1990); Michael J. Levitin, The Treatment of United States Financial Services Firms in Post1992 Europe, 31 Harv. Int'L L. J. 507 (1990); Michael Gruson \& Werner Nikowitz, The Second Banking Directive of the European Economic Community and Its Importance for Non-EEC Banks, 12 Fordham INT'L L. J. 205 (1989).

129. See Yu-Kyung Kim, The Growing Financial Market Importance of Institutional Investors: The Case of Korea, in Institutional Investors in THE New Financial LandsCape 159, 172-173 (OECD 1998). See also Je Won Lee, A Study on Institutional Investors and Their Roles in the Governance Structure of Korea's Publicly Held Companies 224 (Seoul National University Disserta- 
percent held by "foreigners"-who usually are institutions-the practical number may well exceed forty percent. This could affect corporate governance, since there is a greater likelihood of a rational apathy problem where foreign investors hold a small percentage of stock in a company. Foreign investors, especially institutions, may actively involve themselves in corporate governance. However, their interest in corporate performance may be limited in that it is primarily tied to the stock price, not to the firm's long-term business prospects. Moreover, they may well prefer liquidity to control. Consequently, the inactivity and lack of interest by foreign institutional investors-who will hold substantial stakes in Korean firms-may be viewed as a problem.

Nevertheless, although the internationalization of Korean capital markets will not directly result in general improvements in corporate governance of Korean firms, many commentators argue that it is likely to introduce such American concepts as institutional investors activism, ${ }^{130}$ shareholder value, shareholder democracy, ${ }^{131}$ and managerial transparency. The Korean government should continue the effort to loosen its tight grip on capital markets as many other national authorities have done since the mid-1980s. The recent steps taken toward deregulation and complete opening-up of Korean capital markets have upgraded the Korean financial system and, as a consequence, created a more favorable environment for balanced development.

Also, some new laws have been promulgated to bring the Korean financial market up to international standards. For instance, in September 16, 1998, the mutual fund was introduced in Korea through the promulgation of the Securities Investment Company Act, which supplemented the existing Securities Invest-

tion 1997) (in Korean). Contrary to the situation in the United States, public funds in Korea have been passive in equity investments. The total assets held by some 70 public and other funds in Korea have reached 100 trillion won recently. It has been reported they invest less than two percent of their assets in the securities market. See Editorial, Han-Guk Kyongue Shinmun, Oct. 15, 1997, at 11 (urging efficient and responsible management of public funds).

130. The literature discussing the role of institutional investors in corporate governance in the U.S. is voluminous. See, e.g., John C. Coffee, Liquidity Versus Control: The Institutional Investor as Corporate Monitor, 91 Colum. L. Rev. 1277 (1991); Thomas A. Smith, Institutions and Entrepreneurs in American Corporate Finance, 85 CAL. L. REv. 1 (1997); Bernard S. Black, The Value of Institutional Investor Monitoring: The Empirical Evidence, 39 UCLA L. Rev. 895 (1992); Edward B. Rock, The Logic and (Uncertain) Significance of Institutional Shareholder Activism, 79 Geo. L. J. 445 (1991); Bernard S. Black, Agents Watching Agents: The Promise of Institutional Investor Voice, 39 UCLA L. Rev. 811 (1992); Bernard S. Black, Shareholder Passivity Reexamined, 89 Mich. L. Rev. 520 (1990); John C. Coffee, The Folklore of Investor Capitalism, 95 Mich. L. Rev. 1970 (1997) (book review article). For studies in a more comparative style, see INSTrTutional Investors and CoRporate Governance (Theodor Baums, Richard M. Buxbaum and Klaus J. Hopt eds., 1994); Bernard S. Black \& John C. Coffee, Hail Britannia?: Institutional Investor Behavior Under Limited Regulation, 92 Мich. L. Rev. 1997 (1994); G. P. Stapledon, Institutional Shareholders and Corporate Governance (1996); Ronald J. Gilson and Reinier Kraakman, Investment Companies as Guardian Shareholders: The Place of the MSIC in the Corporate Governance Debate, 45 Stan. L. Rev. 985 (1993); Thomas Christian Paefgen, Institutional Investors Ante Portas: A Comparative Analysis of an Emergent Force in Corporate America and Germany, 26 INT'L LAw. 327 (1992); James A. Fanto, The Transformation of French Corporate Governance and United States Institutional Investors, 21 BROOK. J. INT'L L. 1 (1995).

131. For recent developments in Europe, see Paula Dwyer et al., Shareholder Revolt, Bus. WeEK (International Edition), Sept. 18, 1995, at 16-21 (reporting new shareholder activism in European countries). 
ment Trust Business Act. ${ }^{132}$ Mutual funds may have significant impact on the corporate governance of Korean firms, in particular in the control contest context, if aggressive managers oversee them with long-term perspectives. Thus far, securities investment trust companies in Korea exercise voting rights that they hold by the shadow voting rule. This rule, however, has been changed to the extent that the securities investment trust companies may now exercise their voting rights without restriction unless such exercise is to acquire the control over the portfolio companies. ${ }^{133}$ The new Securities Investment Company Act has the same provision. ${ }^{134}$

The developments in the Korean market so far have resulted in some foreign institutions becoming increasingly active and aggressive ${ }^{135}$ in corporate governance issues towards the firms in which they are investing. ${ }^{136}$ One can expect that the influence of foreign institutions will become more visible as the ceiling on foreign stock ownership is abolished and Korean capital markets become more global. Future occurrences of this kind of activism may well provoke a reaction among the Korean public and invite government action. In March 1998, Tiger Management successfully forced SK Telecom, Korea's largest mobile-phone operator, to give outsiders two seats on its board and consult in advance with such outside directors for certain large overseas investments and transactions. ${ }^{137}$

It will be very interesting to see how financial institutions in Korea- both domestic and foreign-view their role in corporate governance as the capital market develops. The discussion of these issues has only just begun in Korea, and will continue to draw keen attention in the future. Recent developments still seem to promote the separation of ownership and control. In Korea, the BerleMeans corporation is part of the future, not just the past.

\section{Globalization of Financing and Corporate Governance}

Due largely to high interest rates in the domestic financial market, an increasing number of Korean firms now raise funds abroad, often by issuing Depository Receipts (DRs) and equity-related debt instruments such as Convertible Bonds in the Euromarket. By the end of 1996, Korean firms raised $\$ 10.6$ billion

132. Other new financial regulations include the Law Concerning Asset-Backed SecuriTIZATION, which was promulgated and went into effect on September 16, 1998, and the HOME MORTGAGE LOAN SECuRITIZation COMPANY Law, promulgated on January 29, 1999, effective from April 30, 1999. See Hwa-Jin Kim, The New Special Purpose Companies in Korea, forthcoming in RECENT TRansformation of Korean SOCiety and Law (1999).

133. See Art. 25-2 of the Act.

134. Art. 31 of the Act.

135. See, e.g., ChosUn ILbo, Feb. 1, 1997, at 11 (reporting that the Korea Investment Trust indicated its intent to support hostile takeover of Midopa should Midopa issue convertible bonds for defensive purposes).

136. See Chosun Ilbo, Feb. 29, 1997, at 11 (reporting Tiger Management's plan to raise voice in the management of Chosun Brewery); MAEIL KYONGJE, Jan. 17, 1998, at 1 (reporting that three foreign investment funds have exercised their minority shareholders' rights).

137. Chosun ILBo, March 21, 1998, at 9; Jon E. Hilsenrath, Tiger Won Telecom Fight, But Locals May Win War, Astan Wall St. J., March 23, 1998, at 19, 28. 
by issuing equity-related overseas securities. ${ }^{138}$ Korean involvment in the U.S. market has also increased, due to the easy access afforded by SEC Regulation $S$ and Regulation 144A. ${ }^{139}$ As the restrictions on raising capital abroad have been abolished on implementation of the agreement with the IMF, ${ }^{140}$ the Korean firms' practice of international financing with securities is expected to increase further. In 1997, Korean listed firms financed nearly $\$ 2$ billion by issuing securities abroad. Of this amount, 64.7 percent were convertible bonds and 31.5 percent were DRs. ${ }^{141}$

These developments may have significant implications for corporate governance in Korea. In particular, many Korean firms have accessed the U.S. capital markets through the issuance of DRs. In order to get their shares admitted to the U.S. securities markets, corporate governance related requirements must be met. ${ }^{142}$ In order to keep their shares listed and traded on NYSE or NASDAQ (as of May 1999, ADRs of four Korean companies were listed on NYSE Pohang Iron \& Steel, Korea Electric Power, Korean Telecom and SK Telecom), the strict periodic reporting requirements must also be fulfilled. In practice, they may face pressure from their foreign owners in the global markets to disclose more information to investors ${ }^{143}$ and manage in their interests. According to a report, Merrill Lynch considered suing some Korean commercial banks that issued DRs for their possible acquisition of bad assets from troubled merchant banks. ${ }^{144}$ Further, Korean managers can be sued by U.S. investors even in the

138. See Ho-Yun Chang, International Listing of Korean Stocks and Stock-related Securities and Its Impact on the Korean Stock Market (Korean), 8 KuJHe KYONGYONG Yongu 151, 152, 18588 (1997).

139. Samsung Electronics was the first Korean issuer placing GDRs under Regulation $S$ and Rule 144A in December 1990, followed by numerous other companies. Regulation S was adopted by the SEC on April 24, 1990 in order to provide safe harbors for offshore distributions and resales of unregistered securities of U.S and foreign issuers. It clarifies the non-applicability of the registration requirements of the SECURITIES ACT OF 1933 to offers and sales of securities that occur outside the United States. See James D. Cox et al., Securities Regulation: Cases and Materials 329 39 (1991). Rule 144A was adopted by the SEC on April 23, 1990 in order to provide a safe harbor exemption from the registration requirements of the SECURITIEs ACT of 1933 for resales of restricted securities to "qualified institutional buyers." See id., at 479-85. Despite SEC's attempts to increase access and to eliminate barriers to foreign participants in U.S. markets, foreign issuers still regard the American market as highly restrictive. See generally Roberta S. Karmel \& Mary S. Head, Barriers to Foreign Issuer Entry Into U.S. Markets, 24 LAW \& PoL'y INT'L Bus. 1207 (1993); Andreas J. Roquette \& Christoph W. Stanger, Das Engagement ausländischer Gesellschaften im US-amerikanischen Kapitalmarkt, 48 WERTPAPIER MITTELUNGEN 137 (1994). For non-U.S. companies listed on the NYSE, see <http://www.nyse.com/international>.

140. See No. 33 of the Korea-IMF Memorandum, supra note 27 ("[A] timetable will be set by end-February 1998 to eliminate restrictions on foreign borrowing by corporations").

141. Due to the sluggish domestic stock market and plunging credit ratings, 42 firms canceled or deferred issuance worth $\$ 3,231.8$ million. From January to October 1998 , Korean firms financed only $\$ 663.6$ million by issuing securities abroad. See Korea Financial Supervisory Commission, Overseas Securities Offerings by Type (visited March 5, 1999) <http://www.fsc.go.kr/kfsc/static/12/ 0107.htm>. In 1996, Korean listed firms financed $\$ 2,586.9$ million by floating securities abroad. See Korea Herald, Dec. 31, 1997, at 13. See also Local Firms Issue 23 Overseas Securities Worth $\$ 2$ Bil. in '97, Korea Herald, Jan. 17, 1998, at 11.

142. Cf. New York Stock Exchange Listed Company Manual, section 3.

143. Cf. Merritt B. Fox, Securities Disclosure in a Globalizing Market: Who Should Regulate Whom, 95 Mich. L. Rev. 2498 (1997).

144. See, e.g., Chosun Ilbo, Nov. 29, 1997, at 11. 
U.S. courts. It is well known that the U.S. courts traditionally exercise wide extraterritorial jurisdiction in securities law cases based upon effects and/or conduct tests. ${ }^{145}$ The monetary interest of holders of DRs in the United States may easily establish U.S. courts' jurisdiction in such cases where a violation of U.S. securities laws by a Korean firm is alleged. ${ }^{146}$ This corporate manager's nightmare is becoming reality, as is evidenced by the recent solicitation of an American insurance company to Korean managers advertising their D\&O liability insurance package. ${ }^{147}$

\section{V. \\ CONCLUSION}

Will we be still discussing the convergence of corporate governance institutions ten years from now? Either functionally or formally, the national corporate governance institutions may converge by that time due to globalization of firms' operational and financing activities, as is evidenced by recent developments in Korea. Still, the answer to the question above may be yes. The dynamics of economic development and changes in the competitive environment of the global markets will continuously require private enterprises to innovate and adapt to new economic circumstances. Methods of doing business will constantly evolve dependent upon each economy's path dependency and/or political decisions; the search for the most efficient system will continue. Comparative corporate governance will matter, especially for emerging market economies. ${ }^{148}$ The focus will also move from the comparative study of the problems of monitoring and disciplining corporate managers to that of assessing various systems "in terms of their ability to encourage and find economic innovation and to promote corporate adaptability." 149

145. See, e.g., Schoenbaum v. Firstbrook, 405 F. 2d 200 (2d Cir. 1968), cert. denied, 395 U.S. 906 (1969); Leasco Data Processing Equipment Corp. v. Maxwell, 468 F. $2 d 1326$ (2d Cir. 1972). See also COX ET AL., supra note 139, at 1333-70; Louis Loss, Extra-territoriality in the Federal Securities Code, 20 HARv. INT'L L. J. 305 (1979).

146. On the other hand, it is not unthinkable that Korean firms with their ADRs issued in the United States will request a U.S. court to enjoin hostile tender offer claiming a violation of the Williams Act. But $c f$., Plessey Company Plc. v. General Electric Company Plc., 628 F.Supp. 477 (D. Del. 1986) (dismissing plaintiff's motion for injunctive relief based upon comity and application of the balancing of interests test). For extraterritorial application of tender offer rules, see generally GunNar Schuster, Die Internationale Anwendung des Börsenrechts 557-89 (1996).

147. The major Korean corporate groups have recently been reported to purchase such insurance for their key managers to protect them from minority shareholders' lawsuit for damages. See Han-Guk Kyongje Shinmun, Feb. 19, 1998, at 11; Maeil Kyongje, Feb. 19, 1998, at 1. According to the Korea Financial Supervisory Commission, a total D\&O insurance premium of 22.5 billion won was paid by them in 1998 .

148. Commenting on Roe, Professor Romano points out that "the lesson to be drawn from the mutability of the corporate form is opaque" because "the legal and institutional differences across the three nations [Germany, Japan, and the United States] make it difficult to ascertain whether one approach to corporate governance is superior to another and whether a superior organizational form could be successfully transplanted into another setting." Romano, supra note 3, at 2021. However, in my opinion, her view cannot be interpreted as negating the necessity of learning the advanced institutional and organizational wisdom from efficient corporate governance institutions by emerging market economies.

149. Milhaupt, supra note 71 , at 867 . 
As far as Korean firms are concerned, the globalization of financing may enhance the efficiency of corporate governance without radical formal changes in its structural relationships with capital markets and financial institutions. The rules of international financial markets and/or the desire and necessity to be recognized as credible participants in global markets will cause Korean firms to innovate their governance structure and endeavor towards more transparent and responsible management. The functional approaches to corporate governance issues described above should be promoted through the opening of capital markets and continuous efforts to reform the infrastructure of domestic capital markets. ${ }^{150}$ The international lending agencies involved in the restructuring of Korea's industrial organization and corporate governance should encourage the functional improvements of the Korean system by introducing fair market discipline to the Korean market and refraining from "recommending" sweeping formal changes in the structural relationships between capital markets, financial institutions, and corporate governance. Both market internationalization and the globalization of Korean firms' financing activities can assure effective market discipline in Korea. Active involvement in international financial markets will facilitate functional convergence of corporate governance institutions.

150. Professor Gilson observes a functional rather than a formal convergence of major (U.S., German, and Japanese) systems because "each system's governance institutions have sufficient flexibility to find a solution [to the question of replacing poorly-performing senior management] within their path dependent limits." According to Professor Gilson, "[the] functional convergence is driven by selection: [a] system that allows poor managers to remain in control will not succeed." Gilson, Globalizing Corporate Governance, supra note 1 , at 8. 
Table 1. Thirty Largest Chabbols in Korea (1997)

(billion won, \%, as of April 1, 1997)

Member Firms:

Shareholders'

Cross

Equity (A)

Guarantees(B):

B/A:

\begin{tabular}{|c|c|c|c|c|}
\hline Hyundai & 57 & 9,842 & 10,085 & 102.47 \\
\hline Samsung & 80 & 14,070 & 2,474 & 17.59 \\
\hline LG & 49 & 8,314 & 2,338 & 28.13 \\
\hline Daewoo & 30 & 7,824 & 10,123 & 129.38 \\
\hline Sunkyoung & 46 & 4,702 & 790 & 16.80 \\
\hline Ssangyoung & 25 & 3,217 & 2,974 & 92.47 \\
\hline Hanjin & 24 & 2,119 & 8,178 & 385.92 \\
\hline $\mathrm{Kia}$ & 28 & 2,289 & 2,535 & 110.77 \\
\hline Hanwha & 31 & 1,243 & 1,982 & 159.34 \\
\hline Lotte & 30 & 2,658 & 553 & 20.81 \\
\hline Kumho & 26 & 1,281 & 1,555 & 121.37 \\
\hline Halla & 18 & 306 & 2,727 & 891.01 \\
\hline Dongah & 19 & 1,383 & 2,799 & 202.39 \\
\hline Doosan & 25 & 807 & 711 & 88.07 \\
\hline Dealim & 21 & 1,117 & 2,863 & 256.18 \\
\hline Hansol & 23 & 1,234 & 627 & 50.82 \\
\hline Hyosung & 18 & 878 & 369 & 42.11 \\
\hline Dongkuk Steel & 17 & 1,117 & 626 & 56.06 \\
\hline Jinro & 24 & 109 & 518 & 473.31 \\
\hline Kolon & 24 & 918 & 778 & 84.80 \\
\hline Kohap & 13 & 529 & 425 & 80.28 \\
\hline Dongbu & 34 & 946 & 878 & 92.82 \\
\hline Tongyang & 24 & 663 & 609 & 91.91 \\
\hline Haitai & 15 & 465 & 265 & 57.02 \\
\hline New Core & 18 & 211 & 364 & 172.48 \\
\hline Anam & 21 & 464 & 1,677 & 361.31 \\
\hline Hanil & 7 & 383 & 827 & 215.76 \\
\hline Keopyung & 22 & 527 & 1,867 & 354.27 \\
\hline Miwon & 25 & 444 & 667 & 150.41 \\
\hline Shinho & 25 & 387 & 1,162 & 300.12 \\
\hline Total & 819 & 70,460 & 64,361 & 91.34 \\
\hline
\end{tabular}

Source: Korea Fair Trade Commission 
Table 2. Major Events in the Turmoil (Nov. 97-Feb. 98)

11.21 Korea applied for the bailout funds with the IMF

12.02 Business at 9 merchant banks suspended

12.03 Korea-IMF agreement

12.05 Coryo Securities suspended

12.06 Halla Group filed for court protection

12.08 Daewoo's takeover of Ssangyong Motor announced

12.10 Business at 5 additional merchant banks suspended Mandatory tender offer requirements lessened

12.11 Foreign ownership ceiling raised to 50 percent

12.12 Dongsuh Securities suspended, filed for court protection

12.15 Guidelines for financial-sector M\&A unveiled

12.16 Currency fluctuation restrictions removed

12.18 Presidential election

12.19 Shinsegi Investment Trust suspended

12.22 Moody's and S \& P's downgraded the foreign currency credit rating of Korea to $\mathrm{Bal}$ and $\mathrm{B}+$, respectively

12.24 Moratorium speculated in financial sector Korea-IMF first supplementary agreement

12.25 G-7 countries' advancement of the bailout package announced

12.26 Chong-gu Group filed for court protection

12.29 18 financial reform bills passed, including amendments to the "real name" system in financial transactions

12.30 Foreign ownership ceiling raised to 55 percent Domestic bond markets fully opened to foreigners

01.13 President-elect met CEOs of 4 largest Chaebols for reform talks

01.14 Nasan Group filed for court protection

01.15 Labor-Reform Committee organized to discuss a layoff bill

01.29 New York agreement for the rescheduling of Korea's short-term corporate foreign debts

02.06 Labor law reform accord

02.14 17 "IMF reform bills" passed, including layoff bill

02.17 Korea-IMF second supplementary agreement 